\title{
Effect of Irrigation Schedules and Crop Establishment Methods on Physiological Processes, Light Interception, Water and Crop Productivity of Wheat under a Semiarid Agro-Ecosystem
}

\author{
Vikrant Singh", R.K. Naresh ${ }^{1}$, Vineet Kumar ${ }^{2}$, Mayank Chaudhary ${ }^{3 *}$, N.C. Mahajan ${ }^{4}$, \\ D.K. Sachan ${ }^{5}$, Akash Pandey ${ }^{6}$, Abhisekh Yadav ${ }^{7}$ and Lali Jat ${ }^{1}$
}

${ }^{1}$ Department of Agronomy, ${ }^{3}$ Department of Genetics \& Plant Breeding, ${ }^{6}$ Department of Plant pathology, ${ }^{7}$ Department of Entamology, Sardar Vallabhbhai Patel University of Agriculture \& Technology, Meerut-250110, U.P., India

${ }^{2}$ Indian Institute of Farming System Research, Modipuram, Meerut-250110, U.P., India

${ }^{4}$ Institute of Agricultural Science, Department of Agronomy, Banaras Hindu University, Varansi-221005,U.P., India

${ }^{5}$ K.V.K. Ghaziabad, Sardar Vallabhbhai Patel University of Agriculture \& Technology, Meerut-250110, U.P., India

*Corresponding author

\begin{tabular}{|c|c|}
\hline \multicolumn{2}{|r|}{ A B S T R A C T } \\
\hline & \multirow{6}{*}{ 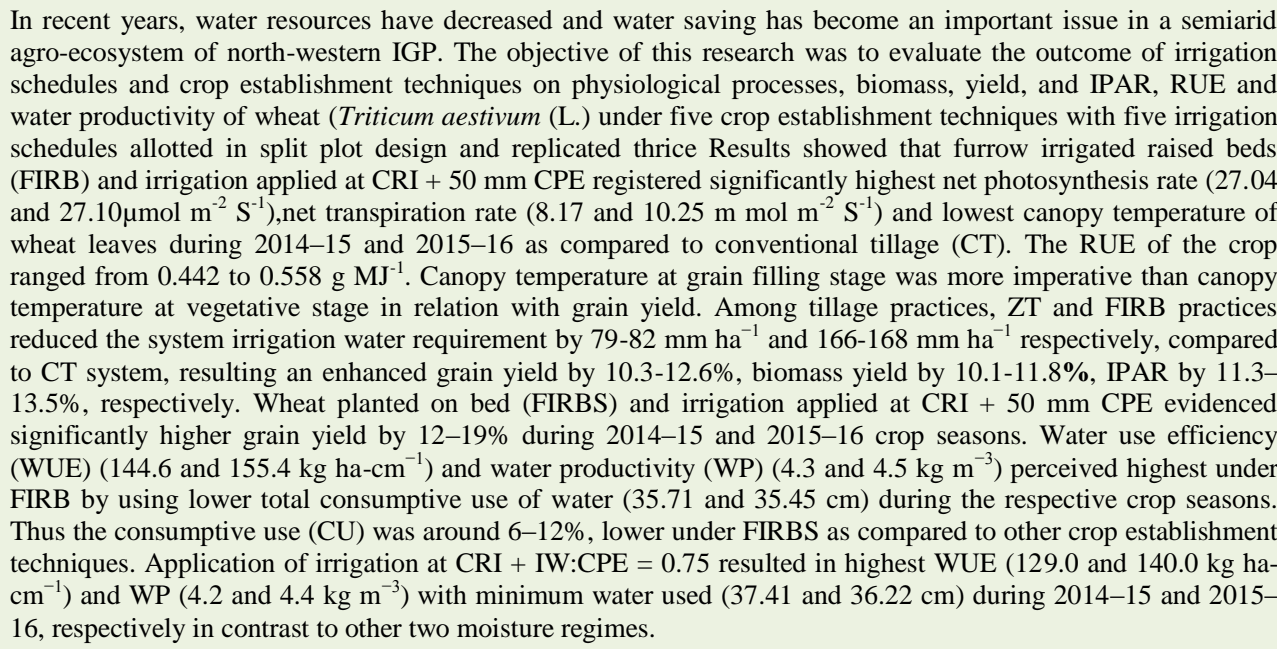 } \\
\hline Keywords & \\
\hline $\begin{array}{l}\text { Physiological processes, } \\
\text { Light interception, } \\
\text { Radiation use efficiency, } \\
\text { Water productivity }\end{array}$ & \\
\hline Article Info & \\
\hline $\begin{array}{l}\text { Accepted: } \\
\text { 24 September } 2018 \\
\text { Available Online: } \\
10 \text { December } 2018\end{array}$ & \\
\hline & \\
\hline
\end{tabular}

\section{Introduction}

Wheat is one of the most important cereal crops of the world on account of its wide adaptability to different agro-climatic and soil conditions and it is the staple food of nearly 35 per cent of the world population. In India, wheat is second most important food crop, 
next only to rice, which is about $13 \%$ share of world wheat production and ranks second in world wheat production next to China which has about $17 \%$ share of world wheat production. The average productivity of India is $3145 \mathrm{~kg} \mathrm{ha}^{-1}$. Wheat occupies 25 per cent of area under food grains and contributes 36 per cent to the total food grain production of the country. In Uttar Pradesh, wheat is grown in typical semi-arid climate which is characterized by high temperature during crop growth. The productivity of Uttar Pradesh is a little lower than that of the country but, far behind if compared to potential yield and advanced wheat cultivating states i.e. Haryana and Punjab. Estimate of productivity of Punjab is $5017 \mathrm{~kg} \mathrm{ha}^{-1}$ during 2013-14 which is $2075 \mathrm{~kg} \mathrm{ha}^{-1}$ higher than that of Uttar Pradesh for the same period (Anonymous, 2015).

The Indo-Gangetic Plain (IGP) of India, covering about $44 \mathrm{Mha}$, is dominated by irrigated cereals-based cropping sequences, of which maize-wheat (MW) rotation is the third most important (1.86Mha) after rice-wheat and cotton-wheat (Jat et al., $2014 a, 2014 b$ ).India is the world's largest user of irrigation water supplied from ground water (Aeschbach-Hertig and Gleeson, 2012). In India and many parts of the world, the irrigation and fresh water resources are increasingly scarce every year due to extensive subsidies and limited regulations (Naresh et al., 2010; Haddeland et al., 2014). Considering this scenario, we can expect that water resources will be less available for irrigated agriculture and competition for water will increase in the near future in this region. Within this context, a large increase in water productivity is required to optimize agricultural productivity while reducing pressure on natural resources (Naresh et al., 2015; Teixeira et al., 2014). In this sense, alternative best crop management options like conservation agricultural practices which include zero tillage and permanent beds have demonstrated potential benefits on crop yield and profits while saving water, energy and restoring soil degradation across diverse ecologies (Jat et al., 2013, 2014a; Das et al., 2014).

Direct planting of crops in zero tillage (ZT) and PB plots, with balanced fertilization lead to favourable alterations in soil water aggregates (Parihar et al., 2016a, 2016b), total porosity (Jemai et al., 2013), maintaining soil and moisture content (Sharma et al., 2011) and, as a consequence, it improved plant water availability (Jemai et al., 2013). Conservation agriculture (CA) based ZT system could provide additional nutrients (Kaschuk et al., 2010), improve soil physical health (Jat et al., 2013; Singh et al., 2016), and better water productivity (Govaerts et al., 2009). A healthy soil is capable of producing higher crop yield under favourable as well as extreme climatic conditions (Congreves et al., 2015). Reduction in soil disturbance (tillage) and provision of optimum crop nutrition can enhance dry matter accumulation and improve plants metabolic activities, resulting in better yield and crop architecture due to plant $\mathrm{x}$ environment interactions (Norman and Campbell, 1989). The absorption of solar radiation depends on crop architecture (Plénet et al., 2000).

Food production and water use are inextricably linked. Water has always been the main factor limiting crop production in much of the world where rainfall is insufficient to meet crop demand. With the ever-increasing competition for finite water resources worldwide and the steadily rising demand for agricultural commodities, the call to improve the efficiency and productivity of water use for crop production, to ensure future food security and address the uncertainties associated with climate change, has never been more urgent. The enhancement of water 
productivity in agriculture is very important. It is widely believed that an increase in agricultural water productivity is the key approach to mitigate water shortage and to reduce environmental problems. In agriculture, water productivity is a useful indicator for quantifying the impact of irrigation scheduling decisions with regard to water management. Water productivity is a useful indicator for quantifying the impact of irrigation scheduling decisions with regard to water management. Water productivity is a useful indicator for quantifying the impact of irrigation scheduling decisions with regard to water management. Irrigation interval largely depends upon environmental conditions, stage of the crop and rainfall received. Evapotranspiration (ET) from cropped area has very close relationship with evaporation of water from open pan evaporimeter. Hence, use of open pan evaporimeter has become important tool for scheduling irrigation.

Improved biomass, grain yield and water productivity would depend on the capacity to improve the amount of photosynthetically active radiation (PAR) intercepted by the crop or the efficiency with which the canopy converts that radiation into new biomass (RUE) at different stages of the crop (Acreche and Slafer 2009). Thus, knowledge of resource capture, particularly, soil moisture, nutrients and radiation by crop species under optimum management can be one of the options in improving the productivity of the crop (Gao et al., 2013; Iqbal et al., 2013). In addition to the radiation interception, understanding the surface energy balance and latent heat flux will provide information on crop water requirement and can be used as an effective tool for irrigation scheduling for dry season crop (Kar and Kumar 2009; Kar et al., 2013). Some researchers opined that the management of deficit irrigation is one of the water saving strategies in agriculture. Under deficit irrigation, the amount of biological or economical yield per unit area is less than that of the maximum production, but the crop water productivity (in terms of crop water use, $\mathrm{kg} \mathrm{m}^{-3}$ ) may be increased by proper irrigation scheduling (Toung et al., 2000; Igbadun et al., 2006).

Different indices of plant water status are controlled by physiological processes which influence the quality and quantity of plant growth. These plant water status parameters are affected by various factors i.e. water and soil management practices. Crop canopy temperature can be used as an estimation of available water in the soil. Canopy temperature (CT), stomatal conductance and water relations traits are linked by the need of plants to transpire water to fix carbon. Cooler CT is positively associated with higher yield under heat and drought stress and both physiological (Lopes and Reynolds, 2010). Stomatal conductance has been proposed as a selection tool and, when measured on multiple plants in a canopy, is equally effective as CT (Condon et al., 2008). Chlorophyll accumulation play vital role in the crop productivity, as they are the only pigments responsible for $\mathrm{CO}_{2}$ assimilation. Its destruction as often observed under water stress in deleterious to the crop productivity. Water stress decreased the chlorophyll content in plant leaves (Zhu and Huang, 1994). Shortterm water stresses in the vegetative phase reduced the chlorophyll content in leaves of wheat genotype (Chandrasekar et al., 2000).

Today's agriculture is an energy intensive farming system (Saharawat et al., 2010). The energy required in agricultural operations, mainly depends on fossil fuels/natural resources which are a scarce commodity. The tillage and crop establishment accounts to 25$30 \%$ cost of the total wheat production cost in rice-wheat (RW) cropping system of South Asia (Naresh et al., 2011; Pathak et al., 2011), leading to lower benefit: cost ratio. Farm 
mechanization plays a vital role for the success of RCT's based on CA in different agro-ecologies and socioeconomic farming groups. It ensures timeliness, precision and quality of field operations; reduces production cost; saves labour; reduces weather risk in the changing climatic scenarios; improves productivity and generates rural employment on on-farm and off-farm activities (Ladha et al., 2009). Our objectives were to: (1) evaluate the effects of irrigation schedule and tillage on crop yields, water productivity, and physiological characteristics of wheat crop within a growing season and (2) to identify the suitable crop establishment method based on their effects on water productivity and profitability in wheat crop.

\section{Materials and Methods}

\section{Experimental site}

The field experiment was established in 2014 at Sardar Vallabhbhai Patel University of Agriculture \& Technology, Meerut, U.P., India research farm $\left(29^{\circ} 04^{\prime}, \mathrm{N}\right.$ latitude and $77^{\circ}$ 42 ', E longitude a height of $237 \mathrm{~m}$ above mean sea level). The region has a semi-arid subtropical climate with an average annual temperature of $16.8^{\circ} \mathrm{C}$. The hottest months are May and June, when the maximum temperature reaches 45 to $46^{\circ} \mathrm{C}$, whereas, during December and January, the coldest months of the year, the temperature often drops below $5^{\circ} \mathrm{C}$.The average annual rainfall is $765 \mathrm{~mm}, 75$ to $80 \%$ of which is received through the Northwest monsoon during July to September. The predominant soil at the experimental site is classified as Typic Ustochrept. Soil samples for 0-20 cm depth at the site were collected and tested prior to applying treatments and the basic properties were non-saline (EC $0.42 \mathrm{dS} \mathrm{m}^{-1}$ ) but mild alkaline in reaction ( $\mathrm{pH}$ 7.98). The soil initially had $4.1 \mathrm{~g} \mathrm{~kg}^{-1}$ of SOC and $1.29 \mathrm{~g} \mathrm{~kg}^{-1}$ of total $\mathrm{N}(\mathrm{TN}), 1.23 \mathrm{~g} \mathrm{~kg}^{-1}$ of total phosphorus, $17.63 \mathrm{~g} \mathrm{~kg}-1$ of total potassium, $224 \mathrm{mg} \mathrm{kg}^{-1}$ of available $\mathrm{N}, 4.0 \mathrm{mg} \mathrm{kg}^{-1}$ of available phosphorus, and $97 \mathrm{mg} \mathrm{kg}^{-1}$ of available potassium.

\section{Experimental design and management}

A detailed description of crop establishment methods are necessary to compare the influence of land configuration practices on environmental performance (Derpsch et al., 2014). The experiment was laid down in split plot design with three replications, keeping planting techniques as main plot and irrigation scheduling as sub-plots. The treatments comprised of five main plots; 1) planting techniques viz. zero tillage (ZT)- $\mathrm{T}_{1}$, reduced tillage (RT)- $\mathrm{T}_{2}$, rotavator tillage (ROT)- $\mathrm{T}_{3}$, furrow irrigated raised bed (FIRB)- $\mathrm{T}_{4}$, conventional tillage $(\mathrm{ZT})-\mathrm{T}_{5}$, and five subplots were of irrigation scheduling viz. Irrigation at CRI- $\mathrm{I}_{1}, \mathrm{CRI}+50 \mathrm{~mm} \mathrm{CPE}-\mathrm{I}_{2}$, CRI + $100 \mathrm{~mm}$ CPE- $\mathrm{I}_{3}$, CRI + $150 \mathrm{~mm}$ CPE$\mathrm{I}_{4}$ and $\mathrm{CRI}+200 \mathrm{~mm}$ CPE- $\mathrm{I}_{5}$.

\section{Cultural practices}

Zero-till (ZT) system of planting crops with minimum of soil disturbance was performed with Zero-till seed drill. By this equipment, seeds were placed directly into narrow slits 2 $4 \mathrm{~cm}$ wide and 4-7 $\mathrm{cm}$ deep made with a drill fitted with chisel, inverted $T$ " without land preparation. In reduced tillage (RT) perse still exists, but numbers of preparatory tillage operations were reduced significantly. One ploughing with harrow followed by one round of cultivator was used before sowing with seed drill in rows $20 \mathrm{~cm}$ apart. Under rotavator tillage (ROT) soil was disturbed prior to planting by rotavator to prepare the seedbed and wheat was sown in zigzag way using a Rototill ferti -seed drill. In case of furrow irrigated raised bed (FIRB) soil was tilled by harrowing and ploughings followed by one field levelling with a wooden plank, and raised 
beds were made using a tractor-drawn multi crop raised bed planter with inclined plate seed metering devices. The dimension of the beds was $40 \mathrm{~cm}$ wide (top of the bed) $x 15 \mathrm{~cm}$ height $\times 30 \mathrm{~cm}$ furrow width (at top) and the spacing from centre of the furrow to another centre of the furrow was kept at $70 \mathrm{~cm}$.

Three rows of wheat were sown on raised bed keeping one row at centre and remaining two at both edges. Following the conventional practice (CT) of two harrowing, three ploughing (using a cultivator) thereafter planking (using a wooden plank) that followed pre-sowing irrigation and wheat was seeded in rows $20 \mathrm{~cm}$ apart using a seed drill with a dryfertilizer attachment.

\section{Fertilizers application and crop management}

In order to raise ideal crop recommended dose of N: P: K (150:60:40) was applied in all treatments. The recommended basal dose of $\mathrm{N}$ @ $75 \mathrm{~kg} \mathrm{ha}^{-1}, \mathrm{P}_{2} \mathrm{O}_{5} @ 60 \mathrm{~kg} \mathrm{ha}^{-1}$ and $\mathrm{K}_{2} \mathrm{O}$ @ $40 \mathrm{~kg} \mathrm{ha}^{-1}$ was applied uniformly as a basal dose using seed-cum-fertilizer drill at the time of seeding operation. $\mathrm{N}$ : P: $\mathrm{K}$ were applied through combination of Urea, DAP and MOP. Rest dose of $\mathrm{N}$ in form of urea was applied in two equal split doses at 25 and 55 DAS synchronizing with irrigation application. Wheat PBW-550 was sown as recommended timely sown variety for North-West-Plain Zone@100 kg ha ${ }^{-1}$. For controlling weeds, pre-sowing spray was done manually by knap sack sprayer. Glyphosate a non-selective presowing herbicide was applied @ $1.0 \mathrm{~kg}$ a.i. $\mathrm{ha}^{-1}$ and post emergence selective herbicide Sulfosulfuron $75 \%$ was applied @ 25 a.i.gha ${ }^{-1}$ + Metasulfuron10\%@4 a.i.g ha ${ }^{-1}$ used after 25 DAS with 420 litre of water during both years of investigation. Harvesting was done manually by improved sickle. The border of individual plot was harvested and separated as a general crop. Thereafter the total biomass production of individual net plot $\left(14.4 \mathrm{~m}^{2}\right)$ was harvested and left in the field for 3 days under sun drying so as to keep the grain moisture level at optimum i.e. $12 \%$.

\section{Scheduling of irrigation}

Five treatments of irrigation water were applied to the plots as per the irrigation schedule. For measuring irrigation water, volume method was used. Irrigations were scheduled on cumulative pan evaporation (CPE) method in individual treatments. Irrigation number and dates of irrigation water applied in each treatment were elaborated in Table 1. The source of irrigation water was Tube well with good quality water for irrigation.

\section{Water use studies}

\section{Evapo-transpiration and Water productivity computations}

Soil moisture content in the profile $(0-90 \mathrm{~cm})$ was determined gravimetrically at viz., 0-15, $15-30, \quad 30-60$ and $60-90 \mathrm{~cm}$ interval of different soil layers at the initial (at sowing) and final stage (at harvesting) of wheat crop grown in winter season to study profile soil moisture contribution in plant growth and development.

For moisture content analysis in permanent bed plots, soil samples were collected from the side of the ridge at the $30 \mathrm{~cm}$ interval using a tube auger of $7 \mathrm{~cm}$ diameter from three places in each experimental treatment.

Evapo-transpiration (ET) was computed using the field water balance equation (Pradhan et $a l ., 2014)$ as given below:

$\mathrm{ET}=(\mathrm{P}+\mathrm{I}+\mathrm{C})-(\mathrm{R}+\mathrm{D}+>\mathrm{S})[1]$

Where; ET is the evapo-transpiration ( $\mathrm{mm}), \mathrm{P}$ is the effective precipitation ( $\mathrm{mm}), \mathrm{I}$ is the irrigation $(\mathrm{mm}), \mathrm{C}$ is the capillary rise $(\mathrm{mm}), \mathrm{R}$ 
is the runoff $(\mathrm{mm}), \mathrm{D}$ is the deep percolation $(\mathrm{mm})$ and $>$ Sis change in the soil profile moisture $(\mathrm{mm})$.As the groundwater level was very low (8-10 $\mathrm{m}$ depth), $\mathrm{C}$ was assumed to be negligible. There was no runoff $(\mathrm{R})$ from the experimental plots as they were bounded up to a sufficient height (40 cm height) and also no case of bund overflow was observed during the study period. As soil moisture studies were made up to a soil depth of $90 \mathrm{~cm}$ and the profile was sandy loam with loamy and clay loam layers having a high bulk density of 1.71-1.72 $\mathrm{Mg} \mathrm{m}^{-3}$ below $60 \mathrm{~cm}$, deep percolation below the $90 \mathrm{~cm}$ profile (D) was assumed to be negligible (Pradhan et al., 2014).Thus Eq. (1) simplifies to,

$$
\mathrm{ET}=(\mathrm{P}+\mathrm{I})->\mathrm{S}[2]
$$

Precipitation data were collected from the meteorological observatory of SVPUAT, Meerut. The effective rainfall was calculated by using Cropwat 8.0 by USDA SCS method. Cropwat is a computer program based decision support tool developed by the Food and Agriculture Organization (FAO) of the United Nations to estimate effective rainfall based on climate and soil data.

The soil moisture data was utilized to calculate the water productivity and soil moisture extraction pattern of the crop for irrigation treatments. Irrigation water was applied using polyvinyl chloride pipes of 15$\mathrm{cm}$ diameter and the amount of water applied to each plot was measured using a water meter (Dasmesh Co., India). The quantity of water applied and the depth of irrigation were computed using the following equations:

Quantity of water applied $(\mathrm{L})=\mathrm{F} \times \mathrm{t}$ [3]

Depth of water applied $(\mathrm{mm})=(\mathrm{L} / \mathrm{A}) / 1,000$ [4]

Where $\mathrm{F}$ is flow rate $\left(\mathrm{L} \mathrm{s}^{-1}\right), \mathrm{t}$ is time ( $\mathrm{s}$ ) taken during each irrigation, and $\mathrm{A}$ is the area of the plot $\left(\mathrm{m}^{2}\right)$.

Rainfall data was recorded using a rain gauge installed within the meteorological station.

The total amount of water (input water) applied was computed as the sum of water received through irrigation (I) and rainfall (R).

Water productivity $\left(W P_{\mathrm{I}+\mathrm{R}}\right) \quad\left(\mathrm{kg} / \mathrm{m}^{3}\right)$ was computed as follows (Humphreys et al., 2008)

$W P_{\mathrm{I}+\mathrm{R}}=$ Grain yield $/[($ Irrigation water applied (I) + Rainfall received by the crop (R)]. [5]

\section{Soil moisture depletion pattern}

Soil moisture depletion pattern from the four layers viz., 0-15, 15-30, 30-60 and 60-90 cm depths was calculated by using the formula given below. Moisture depleted from each layer was calculated by adding all the short period depletion from all the respective depths till the harvest of the crop and percentage depletion at various depths to the total was worked out.

$$
\text { Mai - Mbi }
$$

Moisture depletion

From $\mathrm{i}^{\text {th }}$ layer $(\mathrm{cm})=$

\section{0}

Where,

Mai $=$ Moisture percentage after irrigation in $\mathrm{i}^{\text {th }}$ layer

Mbi $=$ Moisture percentage before irrigation in $i^{\text {th }}$ layer

$\mathrm{ASi}=$ Apparent specific gravity of ith layer $\left(\mathrm{Mg} / \mathrm{m}^{3}\right)$

Di $=$ Depth of $i^{\text {th }}$ layer in $\mathrm{cm}$ 
Intercepted Photo synthetically Active Radiation (IPAR) and Radiation Utilization Efficiency (RUE)

The percentage light interception or IPAR (400-700 nm) under different irrigation and planting techniques was derived by measuring

The incident radiation above the canopy and that transmitted to the ground below the canopy by a $1 \mathrm{~m}$ long quantum light bar (Light transmission meter, EMS-7) as per the following relationship:

$\mathrm{Ii}=\mathrm{Io}-\mathrm{Irc}-\mathrm{It}+\mathrm{Irg}$

Ii $(\%)$ by the canopy $=(I i / I o) \times 100$

Ii = Intercepted photosynthetically active radiation (PAR) by the canopy

Io $=$ Incident PAR on the canopy

Irc $=$ Reflected PAR by the canopy

It $=$ Transmitted PAR through the canopy

Irg $=$ Reflected PAR from the ground

Measurements of radiation at ground level were taken by placing the linear sensor diagonally across the inter-row space with the ends of the sensor coinciding with the centreline of the rows.

All measurements were performed at 1000 to $1400 \mathrm{~h}$ in a clear day at intervals of 7-14 days, depending on weather conditions.

The rate of increase of biomass density, B ( $\mathrm{g}$ $\mathrm{m}^{-2}$ ), is proportional to the absorbed photo synthetically active radiation, APAR (MJ $\mathrm{m}^{-2}$ $\mathrm{d}^{-1}$ ) (Monteith, 1977).

$$
\frac{d B}{d T}=\varepsilon \text { APAR }
$$

Where,

$\varepsilon$ is the radiation use efficiency (RUE) $\left(\mathrm{g} \mathrm{MJ}^{-1}\right)$ (Pitman 2000).

In this study the dry biomass at different stages were measured and corresponding accumulated photosynthetically active radiation (APAR) were computed to estimate RUE using the following relationship:

$\varepsilon\left(\mathrm{g} \mathrm{MJ}^{-1}\right)=\frac{\text { Cumulative biomass }\left(\mathrm{g} \mathrm{m}^{-2}\right)}{\text { Cumulative APAR }\left(\mathrm{MJ} \mathrm{m}^{-2}\right)}$

Daily intercepted solar radiation $\left(\mathrm{MJ} \mathrm{m}^{-2}\right)$ by the crops was obtained as the product of daily incident solar radiation, measured at the agrometeorological station, and the percentage of mid-day light interception.

The mean daily values of intercepted photosynthetically active radiation were calculated by multiplying it with 0.48 following Monteith (1972), Yoshida (1972); Kar et al., (2013).

Measurement of canopy temperature and canopy temperature depression (CTD)

Canopy temperature was recorded during 13:30 - 14:00 hour with the help of a Tele temp model AG-42 infrared thermometer from 60 DAS after sufficient canopy was established at 15 days interval. Three to four separate measurements were made in each treatment and mean value for each plot was calculated. Measurements was made by directing the instrument towards canopy surface held at $0.5-1.0 \mathrm{~m}$ from the edge of the plot and approximately $50 \mathrm{~cm}$ above the canopy at a $30^{\circ}$ angle from the horizontal so as to view the plant parts only. On holding the grip at the above position, the instrument gave canopy temperature $\left(\mathrm{T}_{\mathrm{c}}\right)$ and on pressing the trigger at the front of the hand grip, it gave 
atmosphere temperature $\left(\mathrm{T}_{\mathrm{a}}\right)$. Canopy minus air temperature differential $\left(\mathrm{T}_{\mathrm{c}^{-}} \mathrm{T}_{\mathrm{a}}\right)$ was measured as canopy temperature depression.

Rate of photosynthesis $\left(\mathbf{P}_{\mathbf{n}}\right)$, stomatal conductance (Gs) and transpiration rate $\left(\mathbf{T}_{\mathrm{r}}\right)$

Photosynthetic rate $\left(\mathrm{P}_{\mathrm{n}}\right)$, stomatal conductance (Gs) and transpiration rate $\left(\mathrm{T}_{\mathrm{r}}\right)$ were recorded at the $50 \%$ panicle emergence, anthesis and grain filling stage on 75,90 and 105 DAS respectively. The heading stage (panicle emergence) extends from the time of emergence of the tip of the head from the flag leaf sheath to when the head has completely emerged but has not yet started to flower. The flowering or anthesis stage lasts from the beginning to the end of the flowering period. Pollination and fertilization occur during this period. All heads of a properly synchronized wheat plant flower within a few days and the embryo and endosperm begin to form immediately after fertilization. Early kernel formation occurs during the milk stage or grain filling stage. The developing endosperm starts as a milky fluid that increases in solids as the milk stage progresses. Kernel size increases rapidly during this stage. The instantaneous photosynthetic rate $(\mathrm{PN})$ and stomatal conductance (Gs) of the properly sunlit flag leaf was measured using a LI-6400 portable photosynthesis system (LI-Cor, Inc., Lincoln, Nebraska, USA) during 9:00-11:00 am and 2:00-4:00 pm daily after the start of experiment. Flag leaves chosen from each randomly chosen plant were used for measurements. Of each treatment, 3 samples were measured and average value was recorded for analysis. Photosynthesis is computed from the difference in $\mathrm{CO}_{2}$ between the reference and sample cells of the IRGA. That difference tells us how much $\mathrm{CO}_{2}$ the leaf has taken out of the air. Similarly, the difference in $\mathrm{H}_{2} \mathrm{O}$ tells us how much water vapour the leaf has contributed, and from that we get transpiration and conductance.

\section{Chlorophyll content}

Chlorophyll content was measured during panicle emergence, anthesis and grain filling stages of the crop growth by chlorophyll meter, model no. (SPAD-502). The meter makes instantaneous and non-destructive readings on a plant based on the quantification of light intensity (peak 25 wavelength: approximately $650 \mathrm{~nm}$ : red LED) absorbed by the tissue sample. A second peak (peak wavelength: approximately $940 \mathrm{~nm}$ : infrared LED) is emitted simultaneous with red LED to compensate the thickness leaf.

\section{Statistical analysis}

Experimental data was statistically analyses by the Analysis of variance (ANOVA). The significance of treatment effects were computed with the help of ' $F$ ' (variation ratio) test and to judge the significance of difference between means of two treatments, critical difference (CD) was worked out as describe by Gomez and Gomez (1984).

\section{Results and Discussion}

Canopy temperature $\left(\mathbf{T}_{\mathbf{c}}\right)$ and Canopy temperature depression $\left(\mathrm{T}_{\mathrm{c}}-\mathrm{T}_{\mathrm{a}}\right)\left({ }^{0} \mathrm{C}\right)$

Results showed that periodical changes in canopy treatment variation values were higher during 2015-16 than 2014-15 at all successive stages of crop. Among crop establishment methods treatment $\mathrm{T}_{4}$ (FIRB) for canopy temperature $\left(\mathrm{T}_{\mathrm{c}}\right)$ (Figure $2 \mathrm{a}$ and $\mathrm{b}$ ) and Canopy temperature depression $\left(\mathrm{T}_{\mathrm{c}}-\mathrm{T}_{\mathrm{a}}\right)$ was lower than those under $\mathrm{T}_{5}$ conventional tillage treatment. Whenever the difference in $\mathrm{T}_{\mathrm{c}}-\mathrm{T}_{\mathrm{a}}$ among the irrigation schedule was equal to or less than the difference among the replicated measurements within the treatment, the irrigation schedule were considered similar in climatic parameters and only water quantity values were reported (Figure $3 a$ and $b$ ). 
During 60 to 120 DAS stage crop establishment treatments $T_{4}$ and $T_{5}$ for $\left(T_{c}\right)$ were ranged from 14.8 to $15.5,18.3$ to 18.6 , 15.9 to $16.4,18.4$ to19.1, 15.9 to $16.1,22.1$ to $23.1,20.9$ to $21.3,24.1$ to 24.8 and 27.4 to $28.1^{\circ} \mathrm{C}$, (Figure 2a) whereas; $\mathrm{T}_{\mathrm{c}}-\mathrm{T}_{\mathrm{a}}$ of treatments $\mathrm{T}_{4}$ and $\mathrm{T}_{5}$ were ranged from -0.94 to $-0.43,-2.04$ to $-1.07,-1.90$ to $-1.13-2.13$ to $-1.86-2.38$ to -2.05 and -2.23 to $-1.59^{\circ} \mathrm{C}$, respectively (Figure 3a). However, treatments $\mathrm{T}_{1}$ and $\mathrm{T}_{2}$ obtained the similar results. Treatments $\mathrm{T}_{1}$ were ranged from 15.2 to 15.3 , 18.5 to $18.6,16.1$ to $16.2,18.8$ to $18.9,15.9$ to 16.0, 22.7 to 22.8 and $\mathrm{T}_{2}$ was from 20.9 to $21.0,24.2$ to $24.3,20.1$ to 20.2 and 27.6 to $27.7^{\circ} \mathrm{C}$ at respective stages during experimentation (Figure 2a).

Irrigation schedule, $\mathrm{T}_{\mathrm{c}}, \mathrm{T}_{\mathrm{c}}-\mathrm{T}_{\mathrm{a}}$ under $\mathrm{I}_{2}$ treatment was lower than rest of the treatments during experimentation. Treatments $\mathrm{I}_{3}$ $(\mathrm{CRI}+50 \mathrm{~mm}), \mathrm{I}_{4}(\mathrm{CRI}+150 \mathrm{~mm})$ and $\mathrm{I}_{5}$ (CRI+200 mm) were recorded 14.6, 15.3 and 15.6; 18.2, 18.5 and 18.8; 14.8, 15.9 and 16.9; $17.1,18.5$ and $19.4 ; 14.5,15.0$ and $16.9 ; 20.8$, 21.5 and $23.7 ; 19.2,20.6$ and $21.3 ; 22.8,23.5$ and $24.4 ; 19.2,20.0$ and 20.3;26.7, 27.2 and $27.9^{\circ} \mathrm{C}$ at respective stage, which were 2.6 , $0.3,6.2,7.0,8.2,7.4,7.9,8.5,5.1$ and 4.9 per cent cooler than $\mathrm{I}_{1}(\mathrm{CRI})$ (Figure $2 \mathrm{~b}$ and $3 \mathrm{~b}$ ).

The canopy temperature measurement is used to detect stress in plants based on the assumption that transpired water cools the leaves below the temperature of the surrounding air. As water becomes limited, transpiration is reduced and which leads to increase in leaf temperature due to increased heat load on the canopy because of absorbed radiation (Bhan, 1987).

In the present study lowest canopy temperature was recorded in the FIRB $\mathrm{T}_{4}$ followed by $T_{1}$ and $T_{2}, T_{3}$. The highest was recorded in the treatment $T_{5}$. This might be due to improved relative water content and water potential of plant, which might have helped the treatment $T_{4}, T_{1}$ and $T_{2}$ to maintain optimum temperature (Figure $2 \mathrm{a}$ ).

A declining trend in canopy temperature depression of irrigation practices at different days was reflected in present studies (Figure $3 \mathrm{a}$ and $\mathrm{b}$ ). This has been already investigated by many workers (Gutierrez et al., 2010; Bahar et al., 2011; Gowda et al., 2011 and Shefazadeh et al., 2012), who reported that canopy temperature depression were positively associated with yield under stress conditions.

\section{Stomatal conductance and chlorophyll content}

In the present study crop establishment methods treatment $T_{5}$ (conventional tillage) was found to be significantly superior to all the treatments and recorded highest stomatal conductance $\left(0.90\right.$ and $\left.0.93 \mathrm{~mol} \mathrm{~m}^{-2} \mathrm{~S}^{-1}\right)$. Treatment $\mathrm{T}_{1}$ was found to be significantly superior to the remaining treatments except $\mathrm{T}_{3}$. However, treatment $\mathrm{T}_{4}$ (FIRB) recorded minimum stomatal conductance $(0.56$ and $0.58 \mathrm{~mol} \mathrm{~m}^{-2} \mathrm{~S}^{-1}$ ) during 2014-15 and 2015-16, respectively (Figure 4a). Irrigation schedules with respect to the stomatal conductance mol $\mathrm{m}^{-2} \mathrm{~S}^{-1}$ also found to be significant during the year of study. $\mathrm{I}_{1}$ recorded significantly higher stomatal conductance as compared to all other irrigation schedules.

Stomatal conductance decreased with the beginning of transpiration during 1300-1330 h (peak radiation load) under $\mathrm{I}_{2}$ irrigation schedule at CRI+50 $\mathrm{mm}$ CPE when the stomatal conductance was minimum (Figure 4b). As stomatal conductance increased, the net transpiration rate decreased. Decreased in stomatal conductance was as a result of excess transpiration over water absorption due to rapidly rising transpiration load on saturation deficit (Ehrler et al., 1978b). Slatyer (1967) 
also suggested that the leaf receiving more radiation had higher net transpiration rate and thus lower stomatal conductance.

Among tillage crop establishment methods, treatment $\mathrm{T}_{4} \quad$ (FIRB) was recorded significantly superior chlorophyll content as compared to all other treatment except $T_{1}$ (zero tillage) plots.

Treatment $T_{2}$ was found to be significantly superior to the remaining treatments. $T_{3}$ and $T_{5}$ were at par with each other, however, $\mathrm{T}_{3}$ recorded higher chlorophyll content over $\mathrm{T}_{5}$ treatment which recorded lowest chlorophyll content (Figure 5a). Similarly irrigation differences with respect to the chlorophyll content also proved significant during the year of study. $\mathrm{I}_{2}$ and $\mathrm{I}_{3}$ recorded significantly higher chlorophyll content as compared to $\mathrm{I}_{1}$, $\mathrm{I}_{4}$ and $\mathrm{I}_{5}$, during experimentation.

Chlorophyll is one of the major chloroplast components for photosynthesis in plant and its relative chlorophyll content has a direct relationship with photosynthetic rate. Chlorophyll content in flag leaf is an indicator of the photosynthetic activity and its stability for the conjugation of assimilates biosynthesis (Bijanzadeh and Emam, 2010).

High chlorophyll content is considered to be desirable characteristic, because it indicates a low degree of photo inhibition of photosynthetic apparatus, therefore reducing carbohydrate losses for grain growth (Manivannan et al., 2007). Delayed irrigation scheduling declined the chlorophyll content of the flag leaf in higher CPE treatment $\mathrm{I}_{1}$ and $\mathrm{I}_{5}$ as presented in (Figure 5b). The results of the present study are in conformity of the results reported by previous workers (Iturbe et al., 1998 and Naroui et al., 2012) who have reported $20 \%$ reduction in leaf chlorophyll content under moisture stress.
Net photosynthesis rate and Net transpiration rate

The rate of net photosynthesis $\left(\mu \mathrm{mol} \mathrm{m} \mathrm{m}^{-2} \mathrm{~S}^{-1}\right)$ increased from panicle emergence to anthesis stage thereafter decreased with the advancement of crop stage (Figure 6a and b). Improved moisture supply by land configuration increased the rate of net photosynthesis significantly over conventional method ' $\mathrm{T}_{5}$ '. At all the stages, $\mathrm{T}_{4}$ (FIRB) was found to be significantly superior to all the treatments except $T_{1}$. Treatment $T_{2}(R T)$ was found to be significantly superior to the remaining treatments. Treatments $T_{3}$ and $T_{5}$ were at par with each other, however, $\mathrm{T}_{5}$ recorded minimum rate of net photosynthesis at every stage of crop growth during experimentation. The rate of net photosynthesis at panicle emergence stage was varied $24.62,24.71$ to $19.12,19.16 \mu \mathrm{mol} \mathrm{m}^{-2}$ $\mathrm{S}^{-1}$ and $22.63,23.28$ to $20.62,20.77 \mu \mathrm{mol} \mathrm{m}{ }^{-2}$ $\mathrm{S}^{-1}$ under irrigation schedules, respectively (Figure 6a). It was evidence that due to irrigation schedule and land configuration the partial closure of stomata in response to moisture availability may be responsible for lowering of stomatal conductance and resulted in decreased the net photosynthetic rate of the plant (Fang et al., 2006).

Treatments $\mathrm{T}_{1} \mathrm{ZT}$ and $\mathrm{T}_{4}$ FIRB had higher yielding during 2014-15 and 2015-16 stood first in net photosynthesis rate at all the stages. Similarly irrigation schedule $I_{2}$ and $I_{3}$ were appeared higher yielding levels than other irrigation schedules in relation to net photosynthesis rate at all stages (Figure 6b). The lower rates of photosynthesis in treatments $\mathrm{I}_{4}, \mathrm{I}_{5}$ and $\mathrm{I}_{1}$ may be due to lower moisture content and reduced amount of PAR absorbed by the canopy in these treatments, which was itself the consequence of reduced leaf area index (Figure 6b). Quanqi et al., (2012) also reported the similar findings. 
In our study the increase in net transpiration rate between panicle emergences to anthesis was $2.93,3.91$ and $24.17,31.99 \mathrm{~m} \mathrm{~mol} \mathrm{~m}^{-2} \mathrm{~S}^{-1}$. At grain filling stage treatment $\mathrm{T}_{4}$ obtained maximum net transpiration rate recorded 8.17 and $10.25 \mathrm{~m} \mathrm{~mol} \mathrm{~m}^{-2} \mathrm{~S}^{-1}$ and minimum was 5.11 and $6.42 \mathrm{~m} \mathrm{~mol} \mathrm{~m}^{-2} \mathrm{~S}^{-1}$ under $\left(\mathrm{T}_{5}\right)$ conventional tillage treatment, respectively (Figure 7a). Net transpiration rate at all the growth stages with application of irrigation with $\left(\mathrm{I}_{2}\right) \mathrm{CRI}+50 \mathrm{~mm}$ CPE intervals at 21,39 , 51, 73 and 102 DAS during 2014-15 and 21, 54, 85, 103, 119 and 131 DAS during 2015-16 were higher as compared to all treatments, respectively. All irrigation treatments increased net transpiration rate over $\mathrm{I}_{1}$ irrigation applied only at CRI stage (Figure $7 b)$. These results seem to be in accordance with the results of Gontia and Tiwari (2008); Naresh et al., (2012) who reported that the crop transpiration rate of wheat was highest at mid-season and lowest at maturity or harvest stage.

\section{IPAR under Irrigation schedule and crop establishment methods}

The peak values of IPAR with different crop establishment methods and irrigation treatments have also been presented in Table 3. Averaged across the irrigation schedules, the lowest peak IPAR of $62.8 \%$ was observed for the $\mathrm{I}_{1}$ which was higher from IPAR of $5(74.1 .0 \%), \mathrm{I}_{4}(80.2 \%), \mathrm{I}_{3}(86.9 \%)$, and $\mathrm{I}_{2}$ $(88.2 \%)$ treatments. The $\mathrm{I}_{2}$ and $\mathrm{I}_{3}$ recorded peak IPAR was statistically at par. Averaged over irrigation levels, planting techniques significantly affected the amount of radiation intercepted.

The minimum peak IPAR (75\%) was achieved with $\mathrm{T}_{5}$ (conventional tillage). The crop with $\mathrm{T}_{4}$ treatment recorded peak IPAR of $87 \%$ (Table 3). The increase in IPAR with higher level of irrigations and FIRB planting technique was due to better crop growth, which gave maximum plant height, and total dry matter. Among all the tillage practices the water availability is the most important factor influencing the IPAR (Schneider et al., 2016

\section{RUE under Irrigation schedule and crop establishment methods}

Maximum RUE (in terms of total biomass) under irrigation schedules and crop establishment treatments are presented in Table 5. Among crop establishment treatments, highest RUE of $0.558 \mathrm{~g} \mathrm{MJ}^{-1}$ was obtained in case of $\mathrm{T}_{4}$ but it was statistically at par with $\mathrm{T}_{1}$ which recorded RUE of $0.526 \mathrm{~g}$ $\mathrm{MJ}^{-1}$.

Other crop establishment treatments were different in respect of RUE (Table 3). Averaged over irrigation treatments, RUE of $0.325,0.354,0.380,0.478$ and $0.521 \mathrm{~g} \mathrm{MJ}^{-1}$ were recorded in $\mathrm{I}_{1}, \mathrm{I}_{5}, \mathrm{I}_{4}, \mathrm{I}_{3}$ and $\mathrm{I}_{2}$, respectively.

It appears from our study that under optimal growth conditions where assimilate supply is likely maintained approximately equal to its demand, crop growth rate was optimized and RUE did not decline. The higher incident radiation conversion efficiency in CA-based management practices (ZT and FIRB) were also reported elsewhere by other researchers (Rajcan and Tollenaar 1999; Fahong et al., 2004).

\section{Seasonal evapotranspiration (ET)}

Seasonal evapotranspiration (ET) of wheat crop varied with different tillage practices (Table 2) in 2-years of study. The ET in 2 years was maximum in the CT plots; the FIRB plots registered lowest ET 560-637 mm. FIRB/ZT treatments. The FIRB plots had $16.5-18.8 \%$, lower ET, in wheat crop compared to $\mathrm{CT}$, respectively during the two years of study. 
Table.1 Details of irrigation applied to wheat crop during 2014-15 and 2015-16

\begin{tabular}{|c|c|c|c|c|}
\hline \multirow[t]{2}{*}{ Treatments } & \multicolumn{2}{|c|}{ Dates of irrigation } & \multicolumn{2}{|c|}{ Number of irrigations } \\
\hline & 2014-15 & 2015-16 & 2014-15 & 2015-16 \\
\hline$I_{1}$ (At CRI) & 01.12 .14 & 04.12 .15 & 1 & 1 \\
\hline $\mathrm{I}_{2}(50 \mathrm{~mm})$ & $\begin{array}{l}01.12 .14 \\
19.12 .14 \\
31.01 .15 \\
22.02 .15 \\
23.03 .15\end{array}$ & $\begin{array}{l}04.12 .15 \\
06.01 .16 \\
06.02 .16 \\
24.02 .16 \\
12.03 .16 \\
24.03 .16\end{array}$ & 5 & 6 \\
\hline $\mathrm{I}_{3}(100 \mathrm{~mm})$ & $\begin{array}{l}01.12 .14 \\
31.01 .15\end{array}$ & $\begin{array}{l}04.12 .15 \\
06.02 .16 \\
12.03 .16 \\
03.04 .16\end{array}$ & 2 & 4 \\
\hline $\mathrm{I}_{4}(150 \mathrm{~mm})$ & $\begin{array}{l}01.12 .14 \\
22.02 .15\end{array}$ & $\begin{array}{l}04.12 .15 \\
24.02 .16 \\
03.04 .16\end{array}$ & 2 & 3 \\
\hline$I_{5}(200 \mathrm{~mm})$ & 01.12 .14 & $\begin{array}{l}04.12 .15 \\
12.03 .16\end{array}$ & 1 & 2 \\
\hline
\end{tabular}

Table.2 Soil moisture depletion pattern and seasonal evapo-transpiration at different depths as influenced by tillage techniques and irrigation levels of wheat crop

\begin{tabular}{|c|c|c|c|c|c|c|c|c|c|c|c|c|}
\hline \multirow[t]{4}{*}{ Treatments } & \multicolumn{8}{|c|}{ Soil moisture depletion pattern $(\mathrm{cm})$} & \multirow{3}{*}{\multicolumn{2}{|c|}{$\begin{array}{l}\text { Total soil } \\
\text { moisture } \\
\text { depletion }\end{array}$}} & \multirow{3}{*}{\multicolumn{2}{|c|}{$\begin{array}{l}\text { Seasonal evapo- } \\
\text { transpiration } \\
(\mathrm{ET})(\mathrm{mm})\end{array}$}} \\
\hline & \multicolumn{8}{|c|}{ Depth of soil (cm) } & & & & \\
\hline & \multicolumn{2}{|c|}{$0-15$} & \multicolumn{2}{|c|}{$15-30$} & \multicolumn{2}{|c|}{$30-60$} & \multicolumn{2}{|c|}{$60-90$} & & & & \\
\hline & \multicolumn{8}{|c|}{ 2014-152015-162014-15 2015-162014-15 2015-162014-15 2015-16 } & \multicolumn{2}{|c|}{$2014-152015-16$} & $2014-15$ & \multirow[t]{2}{*}{$2015-16$} \\
\hline \multicolumn{12}{|c|}{ Crop Establishment Methods } & \\
\hline$\overline{T_{1} Z T}$ & 3.3 & 3.4 & 2.6 & 2. & 4.2 & 4.4 & 2.6 & 2.7 & 12.7 & 13.2 & 604 & 678 \\
\hline $\mathrm{T}_{2} \mathrm{RT}$ & 3.4 & 3.5 & 2.0 & 2. & 3.8 & 3.9 & 2.1 & 2.3 & 11.3 & 11.8 & 658 & 735 \\
\hline $\mathrm{T}_{3}$ ROT & 3.7 & 3.8 & 3.0 & 3. & 3.7 & 3.8 & 1.8 & 1.9 & 12.2 & 12.7 & 678 & 762 \\
\hline $\mathrm{T}_{4}$ FIRB & 4.2 & 4.2 & 3.1 & 3. & 4.1 & 4.2 & 3.4 & 3.5 & 14.8 & 15.1 & 560 & 637 \\
\hline $\mathrm{T}_{5} \mathrm{CT}$ & 4.0 & 4.1 & 2.9 & 3. & 3.6 & 3.7 & 1.7 & 1.7 & 12.2 & 12.5 & 687 & 770 \\
\hline Mean & 3.7 & 3.8 & 2.7 & 2. & 3.9 & 4.0 & 2.3 & 2.4 & 12.6 & 13.1 & 637.4 & 716.4 \\
\hline \multicolumn{13}{|c|}{ Irrigation Schedule } \\
\hline $\begin{array}{l}\mathrm{I}_{1} \mathrm{CRI} \\
\end{array}$ & 2.7 & 2.8 & 1.9 & 2. & 2.8 & 2.9 & 1.5 & 1.6 & 8.9 & 9.4 & 595 & 612 \\
\hline $\mathrm{I}_{2} \mathrm{CRI}+50 \mathrm{~mm}$ & 4.7 & 4.8 & 3.4 & 3. & 4.8 & 5.1 & 3.3 & 3.4 & 16.2 & 16.9 & 689 & 773 \\
\hline $\begin{array}{l}\mathrm{I}_{3} \mathrm{CRI}+100 \\
\mathrm{~mm}\end{array}$ & 4.4 & 4.5 & 3.2 & 3. & 4.5 & 4.6 & 2.8 & 2.9 & 14.9 & 15.1 & 674 & 760 \\
\hline $\begin{array}{l}\mathrm{I}_{4} \mathrm{CRI}+150 \\
\mathrm{~mm}\end{array}$ & 3.8 & 3.9 & 2.6 & 2. & 3.9 & 4.1 & 2.2 & 2.3 & 12.5 & 13.0 & 644 & 693 \\
\hline $\begin{array}{l}\mathrm{I}_{5} \mathrm{CRI}+200 \\
\mathrm{~mm}\end{array}$ & 3.1 & 3.2 & 2.2 & 2. & 3.3 & 3.5 & 1.8 & 1.9 & 10.4 & 10.9 & 629 & 682 \\
\hline Mean & 3.7 & 3.8 & 2.7 & 2. & 3.9 & 4.0 & 2.3 & 2.4 & 12.6 & 13.1 & 646.2 & 704.0 \\
\hline
\end{tabular}


Table.3 Soil moisture content (\%) and productivity related as influenced by crop establishment methods planting pattern and irrigation schedule in wheat crop

\begin{tabular}{|c|c|c|c|c|c|c|c|c|c|c|c|c|c|}
\hline \multirow[t]{4}{*}{ Treatments } & \multicolumn{11}{|c|}{ Soil moisture content (\%) } & \multirow{4}{*}{$\begin{array}{c}\text { Peak } \\
\text { IPAR } \\
(\%)\end{array}$} & \multirow{4}{*}{$\begin{array}{c}\text { RUE } \\
\left(\mathrm{g}^{-1}\right) \\
\left.\mathbf{M J}^{-1}\right)\end{array}$} \\
\hline & \multicolumn{4}{|c|}{ 2014-15 } & \multicolumn{7}{|c|}{ 2015-16 } & & \\
\hline & \multicolumn{11}{|c|}{ after sowing (DAS) } & & \\
\hline & 21 & 39 & 51 & 73 & 102 & 21 & 54 & 85 & 103 & 119 & 131 & & \\
\hline \multicolumn{14}{|c|}{ Crop Establishment Methods } \\
\hline $\mathrm{T}_{1} \mathrm{ZT}$ & 16.1 & 17.3 & 15.7 & 14.9 & 14.4 & 16.2 & 17.2 & 15.8 & 14.6 & 14.3 & 14.2 & 86.0 & 0.526 \\
\hline $\mathrm{T}_{2} \mathrm{RT}$ & 15.6 & 16.8 & 15.3 & 14.5 & 14.0 & 15.7 & 16.6 & 15.6 & 14.2 & 13.9 & 13 & 83.0 & 0.507 \\
\hline $\mathrm{T}_{3}$ ROT & 13.3 & 16.2 & 15.0 & 13.8 & 13.5 & 13.5 & 16.2 & 15.2 & 13.5 & 13.3 & 13.1 & 79.0 & 0.486 \\
\hline $\mathrm{T}_{4}$ FIRB & 13.8 & 16.5 & 15.5 & 14.2 & 13.8 & 14.0 & 16.6 & 15.7 & 13.7 & 13.5 & 13.3 & 87.0 & 0.558 \\
\hline $\mathrm{T}_{5} \mathrm{CT}$ & 14.2 & 16.3 & 14.8 & 13.7 & 13.3 & 14.4 & 16.4 & 16.4 & 13.3 & 13.2 & 13.0 & 75.0 & 0.442 \\
\hline Mean & 14.6 & 16.6 & 15.3 & 14.2 & 13.8 & 14.8 & 16.6 & 15.7 & 13.9 & 13.6 & 13. & 82.0 & 0.504 \\
\hline \multicolumn{14}{|c|}{ Irrigation Schedule } \\
\hline $\mathrm{I}_{1} \mathrm{CRI}$ & 14.6 & 16.6 & 14.9 & 12.4 & 11.1 & 14.8 & 16.6 & 15.3 & 12.2 & 10.9 & 10.3 & 62.8 & 0.325 \\
\hline $\mathrm{I}_{2} \mathrm{CRI}+50 \mathrm{~mm}$ & 14.6 & 16.6 & 16.9 & 17.1 & 17.3 & 14.8 & 16.6 & 17.1 & 17.0 & 16.8 & 16.6 & 88.2 & 0.521 \\
\hline $\mathrm{I}_{3} \mathrm{CRI}+100 \mathrm{~mm}$ & 14.6 & 16.6 & 14.9 & 16.8 & 15.4 & 14.8 & 16.6 & 15.3 & 16.0 & 15.1 & 14.2 & 86.9 & 0.478 \\
\hline $\mathrm{I}_{4} \mathrm{CRI}+150 \mathrm{~mm}$ & 14.6 & 16.6 & 14.9 & 12.4 & 14.3 & 14.8 & 16.6 & 15.3 & 12.2 & 14.5 & 13.4 & 80.2 & 0.380 \\
\hline $\mathrm{I}_{5} \mathrm{CRI}+200 \mathrm{~mm}$ & 14.6 & 16.6 & 14.9 & 12.4 & 11.1 & 14.8 & 16.6 & 15.3 & 12.2 & 10.9 & 13.1 & 74.1 & 0.354 \\
\hline Mean & 14.6 & 16.6 & 15.3 & 14.2 & 13.8 & 14.8 & 16.6 & 15.7 & 13.9 & 13.6 & 13.5 & 78.4 & 0.412 \\
\hline
\end{tabular}

Table.4 Effect of crop establishment methods and irrigation schedules on consumptive use (cm) water use efficiency $\left(\mathrm{q} \mathrm{ha}^{-1}\right)$ and water productivity $\left(\mathrm{kg}_{\text {grain }} \mathrm{cm}^{-3}\right)$ of wheat crop

\begin{tabular}{|c|c|c|c|c|c|c|c|c|c|c|}
\hline \multirow[t]{2}{*}{ Treatments } & \multicolumn{2}{|c|}{$\begin{array}{l}\text { Grain yield } \\
\qquad\left(\mathbf{q ~ h a} \mathbf{a}^{-1}\right)\end{array}$} & \multicolumn{2}{|c|}{$\begin{array}{l}\text { Total water } \\
\text { applied }(\mathrm{cm})\end{array}$} & \multicolumn{2}{|c|}{$\begin{array}{l}\text { Consumptive } \\
\text { use }(\mathrm{cm})\end{array}$} & \multicolumn{2}{|c|}{$\begin{array}{c}\text { Water use } \\
\text { efficiency }\left(\mathbf{q} \mathbf{h a}^{-1}\right. \\
\mathrm{cm})\end{array}$} & \multicolumn{2}{|c|}{$\begin{array}{c}\text { Water } \\
\text { productivity (kg } \\
\text { grain } \mathrm{cm}^{-3} \text { ) }\end{array}$} \\
\hline & $\begin{array}{c}2014- \\
15\end{array}$ & $\begin{array}{c}2015- \\
16\end{array}$ & $\begin{array}{c}2014- \\
15\end{array}$ & $\begin{array}{c}2015- \\
16\end{array}$ & $\begin{array}{c}2014- \\
15\end{array}$ & $\begin{array}{c}2015- \\
16\end{array}$ & 2014-15 & 2015-16 & 2014-15 & $2015-16$ \\
\hline \multicolumn{11}{|c|}{ Crop Establishment Methods } \\
\hline $\mathrm{T}_{1} \mathrm{ZT}$ & 41.3 & 45.9 & 33.3 & 33.8 & 18.4 & 19.0 & 2.24 & 2.41 & 1.24 & 1.36 \\
\hline $\mathrm{T}_{2} \mathrm{RT}$ & 40.1 & 42.9 & 36.5 & 37.9 & 19.2 & 19.7 & 2.09 & 2.18 & 1.10 & 1.13 \\
\hline $\mathrm{T}_{3} \mathrm{ROT}$ & 38.2 & 40.4 & 39.9 & 40.1 & 22.2 & 22.8 & 1.72 & 1.77 & 0.96 & 1.01 \\
\hline T $T_{4}$ FIRB & 41.7 & 47.4 & 24.6 & 25.2 & 19.3 & 20.0 & 2.16 & 2.37 & 1.69 & 1.88 \\
\hline $\mathrm{T}_{5} \mathrm{CT}$ & 37.8 & 40.2 & 41.2 & 42.0 & 23.0 & 23.6 & 1.64 & 1.70 & 0.92 & 0.96 \\
\hline Mean & 39.80 & 43.35 & 35.10 & 35.80 & 20.42 & 21.02 & 1.97 & 2.09 & 1.18 & 1.27 \\
\hline \multicolumn{11}{|c|}{ Irrigation Schedule } \\
\hline $\mathrm{I}_{1} \mathrm{CRI}$ & 37.8 & 31.8 & 11.8 & 12.2 & 11.8 & 13.3 & 3.20 & 2.39 & 3.20 & 2.60 \\
\hline $\mathrm{I}_{2} \mathrm{CRI}+50 \mathrm{~mm}$ & 42.1 & 54.9 & 58.7 & 59.2 & 26.7 & 27.2 & 1.58 & 2.02 & 0.72 & 0.93 \\
\hline $\mathrm{I}_{3} \mathrm{CRI}+100 \mathrm{~mm}$ & 41.2 & 52.0 & 46.3 & 47.2 & 21.6 & 22.3 & 1.91 & 2.33 & 0.89 & 1.10 \\
\hline $\mathrm{I}_{4} \mathrm{CRI}+150 \mathrm{~mm}$ & 39.6 & 42.6 & 35.4 & 36.2 & 17.4 & 18.6 & 2.28 & 2.29 & 1.12 & 1.18 \\
\hline $\mathrm{I}_{5} \mathrm{CRI}+200 \mathrm{~mm}$ & 38.3 & 35.4 & 23.3 & 24.2 & 13.7 & 15.4 & 2.79 & 2.30 & 1.64 & 1.46 \\
\hline Mean & 39.80 & 43.35 & 35.10 & 35.80 & 18.24 & 19.36 & 2.35 & 2.27 & 1.51 & 1.46 \\
\hline
\end{tabular}


Table.5 Effect of tillage practices and irrigation schedule on yield attributes and yields of wheat crop

\begin{tabular}{|c|c|c|c|c|c|c|c|c|c|c|c|c|c|c|c|c|}
\hline \multirow[t]{3}{*}{ Treatments } & \multicolumn{10}{|c|}{ Yield attributes } & \multicolumn{6}{|c|}{ Yield $\left(g^{\prime} a^{-1}\right)$} \\
\hline & \multicolumn{2}{|c|}{$\begin{array}{l}\text { Productive } \\
\text { tillers } \mathbf{~ m}^{-2}\end{array}$} & \multicolumn{2}{|c|}{$\begin{array}{l}\text { Spike length } \\
\text { (cm) }\end{array}$} & \multicolumn{2}{|c|}{$\begin{array}{c}\text { Spikelet } \\
\text { spike }^{-1}\end{array}$} & \multicolumn{2}{|c|}{$\begin{array}{l}\text { Grains } \\
\text { spike }^{-1}\end{array}$} & \multicolumn{2}{|c|}{$\begin{array}{c}\text { Test weight } \\
\text { (g) }\end{array}$} & \multicolumn{2}{|c|}{$\begin{array}{l}\text { Grain } \\
\text { yield }\end{array}$} & \multicolumn{2}{|c|}{$\begin{array}{c}\text { Straw } \\
\text { yield }\end{array}$} & \multicolumn{2}{|c|}{$\begin{array}{c}\text { Harvest index } \\
(\%)\end{array}$} \\
\hline & $\begin{array}{c}2014 \\
-15\end{array}$ & $\begin{array}{c}2015 \\
-16\end{array}$ & $\begin{array}{c}2014 \\
-15\end{array}$ & $\begin{array}{c}2015 \\
-16\end{array}$ & $\begin{array}{c}2014 \\
-15\end{array}$ & $\begin{array}{c}2015 \\
-16\end{array}$ & $\begin{array}{c}2014 \\
-15\end{array}$ & $\begin{array}{c}2015 \\
-16\end{array}$ & $\begin{array}{c}2014 \\
-15\end{array}$ & $\begin{array}{c}2015 \\
-16\end{array}$ & $\begin{array}{c}2014 \\
-15\end{array}$ & $\begin{array}{c}2015 \\
-16\end{array}$ & $\begin{array}{c}2014 \\
-15\end{array}$ & $\begin{array}{c}2015 \\
-16\end{array}$ & $\begin{array}{c}2014 \\
-15\end{array}$ & $\begin{array}{c}2015 \\
-16\end{array}$ \\
\hline \multicolumn{17}{|c|}{ Crop Establishment Methods } \\
\hline $\mathrm{T}_{1} \mathrm{ZT}$ & 214.8 & 222.5 & 11.5 & 11.6 & 16.2 & 16.5 & 53.2 & 55.6 & 36.0 & 36.3 & 41.3 & 45.9 & 64.8 & 65.9 & 38.88 & 41.0 \\
\hline $\mathrm{T}_{2} \mathrm{RT}$ & 211.1 & 217.1 & 10.8 & 11.0 & 16.0 & 16.5 & 51.8 & 55.0 & 34.9 & 35.1 & 40.1 & 42.9 & 63.5 & 65.7 & 38.70 & 39.7 \\
\hline $\mathrm{T}_{3} \mathrm{ROT}$ & 208.2 & 216.4 & 10.0 & 10.1 & 14.9 & 15.2 & 51.4 & 54.2 & 34.6 & 34.9 & 38.2 & 40.4 & 60.9 & 59.7 & 38.54 & 40.7 \\
\hline$\overline{T_{4} \text { FIRB }}$ & 217.9 & 229.8 & 12.1 & 12.3 & 17.1 & 17.2 & 53.9 & 56.5 & 36.5 & 36.4 & 41.7 & 47.4 & 66.6 & 66.2 & 38.52 & 42.0 \\
\hline $\mathrm{T}_{5} \mathrm{CT}$ & 206.2 & 214.2 & 10.0 & 10.1 & 14.7 & 15.1 & 51.1 & 54.1 & 34.4 & 34.9 & 37.8 & 40.2 & 59.8 & 58.1 & 38.73 & 41.1 \\
\hline$C D(P=0.05)$ & 5.65 & 8.12 & 1.05 & 1.15 & 1.92 & 1.76 & 2.46 & 2.35 & 1.28 & 1.25 & 1.02 & 0.71 & 1.95 & 1.95 & - & 1.03 \\
\hline \multicolumn{17}{|c|}{ Irrigation Schedule } \\
\hline $\mathrm{I}_{1} \mathrm{CRI}$ & 179.9 & 188.4 & 9.6 & 9.5 & 13.3 & 13.5 & 44.7 & 47.9 & 32.3 & 32.8 & 31.8 & 37.8 & 44.8 & 60.6 & 38.42 & 41.5 \\
\hline $\mathrm{I}_{2} \mathrm{CRI}+50 \mathrm{~mm}$ & 227.3 & 239.2 & 12.4 & 12.8 & 18.2 & 18.5 & 59.5 & 61.9 & 38.6 & 38.2 & 42.1 & 54.9 & 66.2 & 78.9 & 38.89 & 39.7 \\
\hline $\mathrm{I}_{3} \mathrm{CRI}+100 \mathrm{~mm}$ & 224.2 & 235.8 & 11.6 & 11.8 & 17.5 & 17.7 & 58.0 & 59.6 & 37.2 & 37.9 & 41.2 & 52.0 & 64.2 & 75.8 & 39.11 & 40.7 \\
\hline $\mathrm{I}_{4} \mathrm{CRI}+150 \mathrm{~mm}$ & 217.1 & 226.2 & 11.1 & 11.2 & 15.8 & 16.3 & 53.1 & 55.7 & 35.0 & 35.3 & 39.6 & 42.6 & 63.3 & 62.9 & 38.49 & 40.4 \\
\hline $\mathrm{I}_{5} \mathrm{CRI}+200 \mathrm{~mm}$ & 209.8 & 210.4 & 9.6 & 9.7 & 14.0 & 14.4 & 46.3 & 50.5 & 33.1 & 33.5 & 38.3 & 35.4 & 61.2 & 48.7 & 38.45 & 42.2 \\
\hline$C D(P=0.05)$ & 6.43 & 10.46 & 0.89 & 1.19 & 1.22 & 1.79 & 2.24 & 2.23 & 1.04 & 1.18 & 0.47 & 0.72 & 1.09 & 2.49 & 0.49 & 1.14 \\
\hline
\end{tabular}

Fig.1 Weekly precipitation, evaporation, temperature, relative humidity and wind velocity during the experimental season rabi 2014-15 (a) and 2015-16(b)
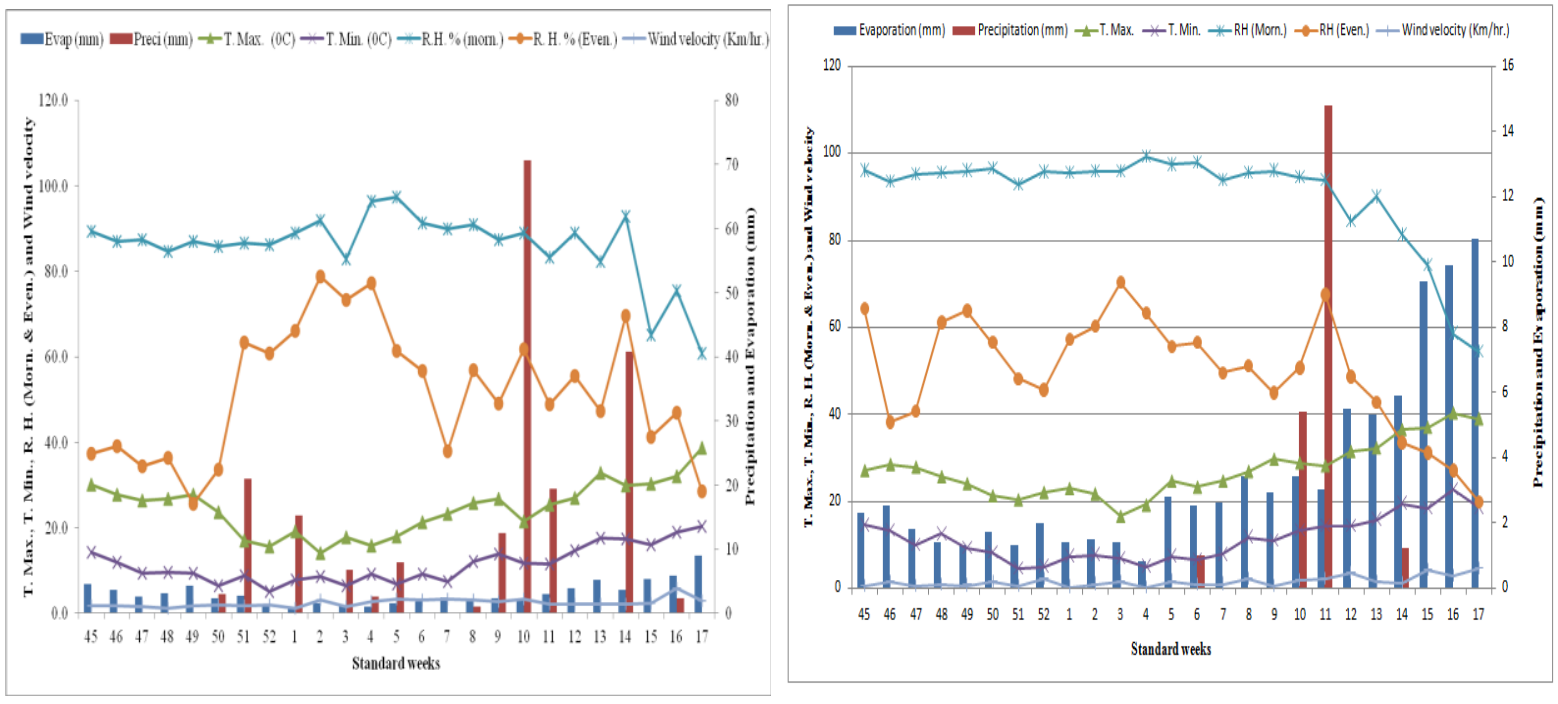

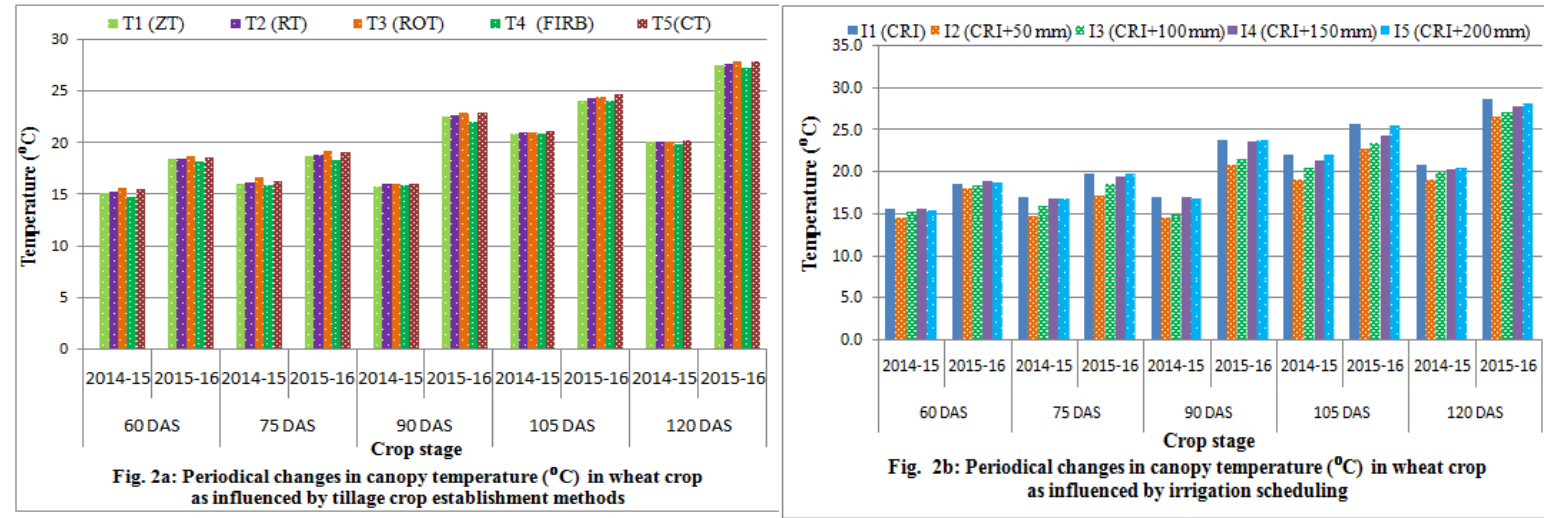

Fig. 2b: Periodical changes in canopy temperature $\left({ }^{\circ} \mathrm{C}\right)$ in wheat crop as influenced by irrigation scheduling
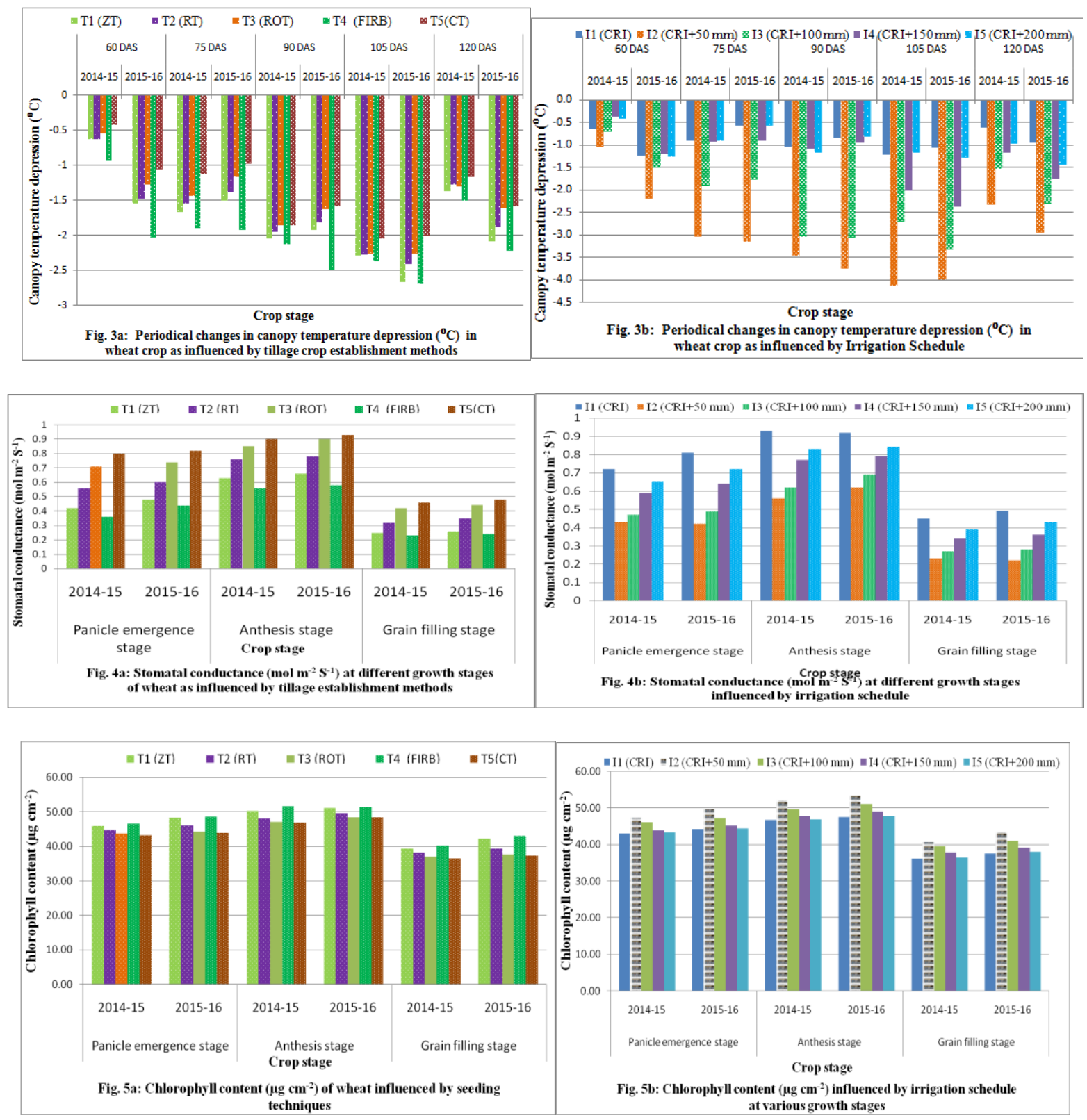


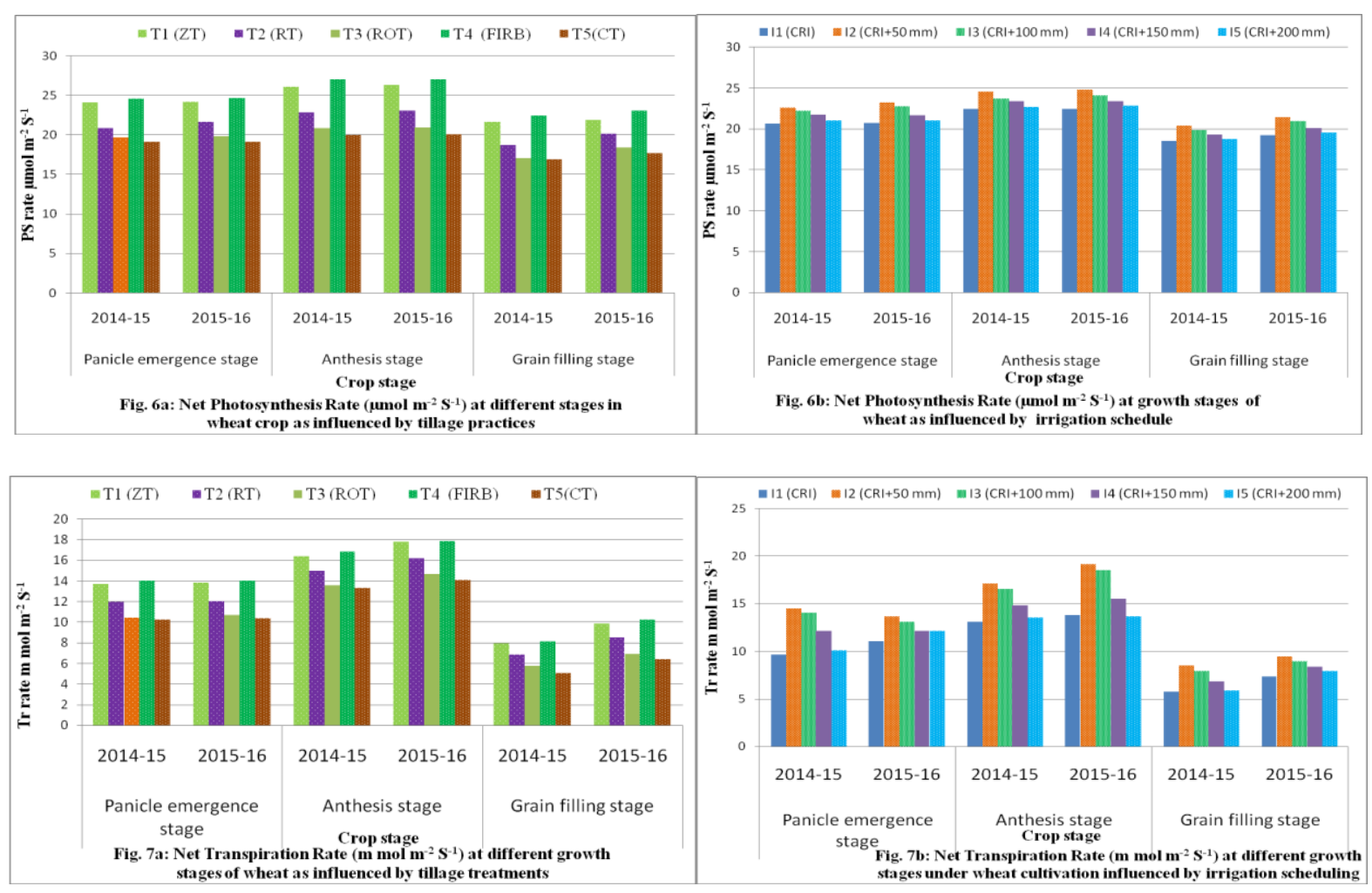

In the study years, irrigation was different between treatments and ET decreased with In conservation agriculture, retention of plant residues on the soil surface results in declined evaporation which mainly attributed with the lower soil temperature (Gupta and Jat, 2010; Naresh et al., 2011) compared to CT. Water moves back to the atmosphere in vapour phase through straw mulch/residue retention on the soil surface in ZT/FIRB whereas no such barrier present in CT. Similar to tillage effects, in all the study years the main effect of irrigation schedule was also influenced the ET. Irrespective of study years, higher ET in $\mathrm{I}_{2} \mathrm{CRI}+50 \mathrm{~mm}$ treatment resulted due to higher biomass production than all other treatments including irrigation at $\mathrm{I}_{1} \mathrm{CRI}$ stage only. During the study years ET in $\mathrm{I}_{2} \mathrm{CRI}+50$ $\mathrm{mm}$ plots higher by $1.9-2.6 \%$, than irrigation at $\mathrm{I}_{1} \mathrm{CRI}$ stage plots (Table 2).

\section{Moisture extraction pattern}

The soil profile was divided in four layers ( 0 $15,15-30,30-60$ and $60-90 \mathrm{~cm}$ ) and the scrutiny of soil moisture extraction pattern within layers reveal that maximum amount of water was extracted (absorbed) from 30-60 $\mathrm{cm}$ layer followed by $0-15 \mathrm{~cm}, 15-30 \mathrm{~cm}$, and minimum from $60-90 \mathrm{~cm}$ during both the year of study. The moisture extraction from the surface layer $(0-15 \mathrm{~cm})$ was increased slightly with land configuration under furrow irrigated raised beds practices during both the year of study. Similarly, the moisture extraction was decreased slightly with increase in profile depth and maximum decrease was observed under rotavator tollage practices (1.8 and 1.9) at $61-90 \mathrm{~cm}$ soil layer due to excessive tillage during 2014-15 and 2015-16, respectively (Table 2). Our results indicated that FIRB and zero till plots retained high moisture from the deeper soil layer than conventional and rotavator tillage practice during the year of study. The declining contribution of deeper soil layer to total crop water use trend was also observed by Dhaka et al., 2007. However, Maurya and Singh 2008 find that the crop establishment method affected the moisture depletion pattern, maximum total 
moisture depletion (24.07 and $22.83 \mathrm{~cm}$ ) by wheat crop from each layer was recorded under conventional method of sowing as compared to the rest of the methods, such as zero tillage, rota till drill and bed planting method of crop establishment due to more availability of moisture in rhizosphere. The amount of moisture depleted decreased with the soil depth due to lower density of roots in deeper layer compared with the upper layer. Due to increased surface evaporation the percentage contribution of upper $30 \mathrm{~cm}$ layer was more. The highest moisture depletion under the conventional method might be due to less availability of moisture at upper layer and more evaporation from upper surface. Similar results have been reported by Zaman et al., 2006; Naresh et al., 2013a and Ram et al., 2013.

\section{Soil moisture content studies}

In general, the profile moisture content was highest at the time of sowing $(21 \%)$ and it was lowest at the time of crop maturity in all the treatments during both the year of study. The increases in profile moisture content are visible from the peaks under tillage practices, difference were because of moisture conserved due to the application of irrigation as per CPE i.e. climatic approach treatments. The moisture content of conventional tilled plots $\left(\mathrm{T}_{5}\right)$ was always lower than zero and reduced tillage plots $\left(T_{1} \& T_{2}\right)$ during the year of study except in the peaks where the moisture content in the profile was always same due to recharging of profile by application of irrigation. In between the season the lowest soil moisture content was in conventional till and rotavator till plots were 51 DAS (15.0 and 14.8\%), 73 DAS (13.8 and $14.2 \%)$ and 102 DAS (13.5 and 13.3\%) during 2014-15, whereas, the lowest soil profile moisture content during 2015-16 were recorded at 54 DAS (16.2 and 16.4\%), 85 DAS (15.2 and 16.4\%) and 103 DAS (13.5 and $13.3 \%$ ), respectively (Table 3 ). The conventional till crop under irrigation schedule treatments were kept the average profile soil moisture content $1.5 \%$ lower than zero tillage plots throughout the crop season except after recharging the soil profile either by application of irrigation or by rainfall. Similar results have been reported by Jat et al., 2013; Naresh et al., 2012.

\section{Consumptive use}

The consumptive use of water (23.0 and 23.8 $\mathrm{cm})$ was more under conventional method $\left(\mathrm{T}_{5}\right)$ (Table 4) followed by the ROT $\left(\mathrm{T}_{3}\right)$, FIRB $\left(\mathrm{T}_{4}\right)$ and lowest value of consumptive use was recorded under $\mathrm{ZT}\left(\mathrm{T}_{1}\right)$ crop establishment methods during the year of study. The consumptive use of water directly related with moisture depletion and it was higher under flat conventional method and lowest under zero till plots.

Consumptive use of water showed an increasing trend with increase in irrigation water depth during experimentation. The consumptive use of water $(23.76$ and $23.6 \mathrm{~cm})$ was more under conventional method and lowest value of consumptive use was recorded under ZT plots. The consumptive use of water directly related with moisture depletion and it was higher under conventional method and lowest under zero tillage. The highest consumptive use (26.7 and $27.2 \mathrm{~cm}$ ) was recorded with irrigation schedule at CRI+50 $\mathrm{mm}$ CPE. This was mainly due to fact that the greater loss of applied water through evapotranspiration because of more availability of water resulted into better foliage and ultimately better plant growth. As a result of this greater absorption of moisture by crop favoured by highest water use at wettest regime. In contrast, the lowest consumptive use of water $(11.8$ and $13.3 \mathrm{~cm})$ was under the irrigation schedule at CRI stage $\left(\mathrm{I}_{1}\right)$ due to combination of lower surface 
evaporation and reduced transpiration under lower moisture availability. These findings are supported by Singh et al., 2010a,b; and Mandhata et al., 2012; Doorenbos and Pruit (1982) who reported that the water requirements of wheat for maximum production varied between 450 and $600 \mathrm{~mm}$ per season depending on climate and length of growing period.

\section{Water use efficiency and water productivity}

The crop water use efficiency was decreased markedly in conventional till plots $\left(\mathrm{T}_{5}\right)$ than FIRB $\left(\mathrm{T}_{4}\right)$ and zero till plots $\left(\mathrm{T}_{1}\right)$ during the year of study. Maximum WUE was recorded under ZT followed by FIRB, RT and ROT during experimentation. The water productivity increased with the increased yield during experimentation. Water productivity was recorded in order of FIRB $>$ ZT $>$ RT $>$ ROT $>$ CT. This might be due to higher grain yield obtained under FIRB $\left(\mathrm{T}_{4}\right)$ treatment with lesser amount of water used. Declined water-use efficiency (WUE) under irrigation schedule at CRI stage $\left(\mathrm{I}_{1}\right)$ might be due to fact that grain yield did not increase proportionately to that of consumptive use under this treatment and water-use efficiency decreased due to moisture stress.

Similar result found by Li et al., 2009; Singh et al., 2010a,b; Naresh et al., 2014a; Singh and katiyar 2014; Singh et al., 2015. It was reported that in general, the wheat WUE ranges from 0.40 to $1.83 \mathrm{kgm}^{-3}$ globally on a yield basis. For example, with the irrigated wheat in the US southern plains, WUE was $0.50-1.20 \mathrm{kgm}^{-3}$ with a yield of $3000-8000$ $\mathrm{kgha}^{-1}$ (Musick et al., 1994). A high efficiency of water use is extremely important for farmers and irrigation agencies in water scarce areas.
The maximum water productivity was

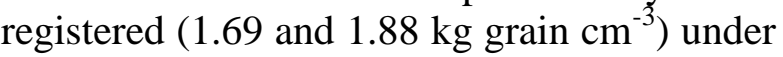
FIRB planting pattern, followed by zero tillage planting method during the year of study (Table 4). In general, water productivity affected of different irrigation schedule treatments and higher water productivity (1.64 and 1.46kggrain $\mathrm{cm}^{-3}$ ) was observed irrigation at CRI $+200 \mathrm{~mm}$ CPE during experimentation. However, minimum water productivity (072 and $0.93 \mathrm{~kg}$ grain $\mathrm{cm}^{-3}$ ) was observed under irrigation at $\mathrm{CRI}+50 \mathrm{~mm} \mathrm{CPE}$ treatment. Decrease in water productivity at CRI+50 mm CPE was based on the fact that the proportionate increase in grain yield was less than increase in the amount of water. This might be due to the fact under more irrigation, evaporation was at potential rate due to availability of more water than the crop irrigated with less irrigation, and this finding is in close conformity with Sharma and Yadav (2010), Aggrwal et al., (2013), Naresh et al., (2014b). and Singh et al., (2015).

\section{Yield attributes}

The scrutiny of data as in (Table 5) revealed that $\mathrm{T}_{4}$ (FIRB) treatment significantly increased yield attributes i.e. productive tillers $\mathrm{m}^{-2}$, spike length $(\mathrm{cm})$, spikelet spike ${ }^{-1}$, grains spike $^{-1}$ and test weight (g) over $\mathrm{T}_{2}, \mathrm{~T}_{3}$ and $\mathrm{T}_{5}$ treatments but at par with $\mathrm{T}_{1}$ treatment during the year of study. However, $\mathrm{T}_{2}$ treatment produced significantly increased yield attributes as compared to $\mathrm{T}_{3}$ and $\mathrm{T}_{5}$, respectively. The higher yield obtained under these planting system might be owing to cumulative effect of number of grains spike ${ }^{-1}$ due to improvement of soil - moisture and mineral nutrient availability Dhindwal et al., (2006) and Tripathi and Singh (2007) reported similar findings. Irrigation management differences with respect to the yield attributes were also found to be significant. Treatments $\mathrm{I}_{1}$ and $\mathrm{I}_{5}$ were produced significantly lower yield attributes 
as compare to rest of the irrigation schedule during experimentation. Treatment $\mathrm{I}_{2}$ produced significantly higher yield attributes as compared to all other treatments except $\mathrm{I}_{3}$ in both the year of study. This was because the water stress resulted in imposed on nutrient translocation, photosynthesis and metabolic activity in the planting system. Chauhan et al., (2008) who stated that application of five irrigations to wheat crop resulted in the highest grain yield. This result corroboration the findings of Bharti et al., (2007).

\section{Yield studies}

The grain $\left(41.7,47.4 \mathrm{q} \mathrm{ha}^{-1}\right)$, straw $(66.6,66.2$ $\mathrm{q} \mathrm{ha}^{-1}$ ) yields and harvest index (38.88 and 42.00) were recorded significantly higher (Table 6) with tillage crop establishment treatment $\mathrm{T}_{4}$ (FIRB) as compared to all other treatments except $\mathrm{T}_{1}$ (ZT) (41.3, $46.0 \mathrm{qha}^{-1}$ and 64.8, 65.9 $\mathrm{qha}^{-1}$ ) during experimentation. The grain yield increased 6.6, $7.3 \%$, straw yield 7.0, $7.3 \%$ with tillage crop establishment methods over conventional planting during first and second year, respectively. Treatments $\mathrm{T}_{2}(\mathrm{RT})$ and $\mathrm{T}_{3}$ (ROT) were at par with each other during the year of study. However, $\mathrm{T}_{5}(\mathrm{CT})$ was recorded the lowest grain yield during experimentation. The irrigation schedules having good tillering and higher rates of photosynthesis, had high biomass production and therefore was more suited for furrow irrigated raised bed planting system than flat planting. However, yield advantage in furrow irrigated raised bed planting system over conventional flat planting system. Farmers can easily respond to this technology if efforts are diverted to demonstrate yield differences between flat and bed planting systems either by modifying land configuration or crop rows planted on the top of the beds or selection of suitable irrigation schedule.
The grain and straw yield per hectare were increased with every successive increase in moisture supply through irrigation schedule. The highest grain yield $\left(49.9,54.8 \mathrm{q} \mathrm{ha}^{-1}\right)$ and straw yield $\left(66.2,78.9 \mathrm{q} \mathrm{ha}^{-1}\right)$ were found to be under $I_{2}$ treatment where 5 and 6 postplanting irrigation excluding the common irrigation, were given during first and second year of experimentation. Lowest yield (31.8, 37.8 and 44.8, $60.6 \mathrm{q} \mathrm{ha}^{-1}$ ) was under $\mathrm{I}_{1}$ treatment. The yield per hectare was primarily improved due to improvement in moisture supply and its beneficial effect on the yield per plant. The significantly higher grain, straw yields and harvest index was obtained in $\mathrm{CRI}+50 \mathrm{~mm} \quad \mathrm{CPE} \quad 0.8 \quad\left(\mathrm{I}_{2}\right)$ irrigation schedules and increased the grain yield 17.27 and $17.02 \%$ over irrigation at CRI $\left(\mathrm{I}_{1}\right)$. The yield per plant improved with increased moisture supply mainly through improvement in number of effective tillers, number of grains per spike and test weight (Table 5). Similar trend have been observed by Rani et al., 2009; Rahman et al., 2010; Naresh et al., 2014a and Kumar et al., 2015.

In this study, generally, the results showed that the means of growth and yield attributes of wheat under irrigation schedule was relatively lower in the first season than in the second season due to the weather climate condition. The highest grain yield from (irrigation at CRI $+50 \mathrm{~mm}$ CPE stage and irrigation at CRI skipping at seedling, dough and repining stages) might be obtained due to availability of enough moisture at critical stages tillering and booting. It could be conclude that tillering and booting are the most important critical stages in the wheat crop regarding requirement of water, while the irrigation at repining decrease in wheat yield.

FIRB plots responded better under CRI +50 $\mathrm{mm}$ CPE because this planting system require lower amount of water and can be irrigated 
frequently in a very short duration thus, FIRB, a new technology should be disseminated in wheat growing areas for increasing production and productivity of wheat under intensive farming system category. To overcome the shortage of irrigation water, it is therefore, essential that we must use the available water resources carefully. In this regard, besides improvement in the system, over and under irrigation to crops should be avoided and irrigations be applied on crop water requirement basis using modern methods of irrigation.

The zero tillage crop establishment technology requires shortest duration for field preparation helps in matching the optimum climatic conditions and can be performed with residual moisture condition. These opportunities helps in better growth as well as higher physiological performance viz. net photosynthesis rate, chlorophyll content, net transpiration rate and lower stomata conductance resulting in higher shoot growth obtained from better root growth due to favourable soil properties. Such soil and soil moisture characteristics resulted in better growth parameters and resulted in higher yield attributes and yield with minimum input.

\section{Acknowledgements}

This work was supported by Uttar Pradesh Council of Agricultural Research, Lucknow on "Resource Conservation Technologies for Sustainable Development of Agriculture" is gratefully acknowledged by the authors. We are grateful to the authorities of the Sardar Vallabbhai Patel University of Agriculture \& Technology, Meerut, U.P., India for all support in execution of this experiment. We also acknowledge the technical support from. Moreover, we would like to express our great respect for the editors and anonymous reviewers to improve the manuscript quality.

\section{References}

Acreche, M.M. and Slafer, G.A. 2009. Grain weight, radiation interception and use efficiency as affected by sink-strength in Mediterranean wheat released from 1940 to 2005. Field Crops Res. 110, 98-110.

Aeschbach-Hertig, W. And Gleeson, T., 2012. Regional strategies for the accelerating global problem of groundwater depletion. Nat. Geo. Sci. 5, 853-861.

Aggarwal, P., Mittal, R.B., Maity, P. and Sharma, A.R. 2013. Modification of hydrothermal regimes under bed planted wheat. Geoderma 153: 312-317

Bahar, B., Yildirim, Y. and Yucel, C. 2011. Heat and drought resistance criteria in spring bread wheat (Triticum aestivum L.) morphophysiological parameters for heat tolerance. Sci. Res. Essays. 6 (10): 2212-2220

Bhan, S. C. 1987. Canopy temperature in relation to plant growth under different moisture levels in wheat. M.Sc. (Agri.) Thesis, Chaudhary Charan Singh Haryana Agricultural University, Hisar.

Bharti, V., Nardar, R., Kumar Vinod and Pandey, I.S. 2007. Effect of irrigations level on yield, water use efficiency and economics of winter maize (Mdiar). Indian J. Agron., 52 (1):27-30.

Bijanzadeh, E. and Emam, Y. 2010. Effect of source-sink manipulation on yield components and photosynthetic characteristic of wheat cultivars (Triticum aestivum and T. durum L.). J. Applied Sci., 10: 564-569.

Chandrasekar, V., Sairam, R. K. and Srivastava, G. C. 2000. Physiological and biochemical response of hexaploid and tetraploid wheat to drought stress. J Agron 185: 219-227.

Chauhan, C.P.S., Singh, R.B. and S.K. Cupta. S.K. 2008. Supplemental irrigation of wheat with saline water. Agri water Manag 95: 253-258.

Condon, A. G., Reynolds, M. P., Rebetzke, G. J., van Ginkel, M., Richards, R. and Farquhar, G. 2008. Stomatal aperture related traits as early generation selection criteria for high yield potential in bread wheat. International Symposium on Wheat Yield Potential: Challenges to International Wheat Breeding. Mexico, D.F.: CIMMYT

Congreves, K.A., Hayes, A., Verhallen, L.L. and Van Eerd, L.L., 2015. Long term impact of tillage and crop rotation on soil health at four 
temperate agro ecosystems. Soil Till Res.152:17-28.

Das, T.K., Bhattacharyya, R., Sudhishri, S., Sharma, A.R., Saharawat, Y.S., Bandyopadhyay, K.K., Sepat, S., Bana, R.S., Aggarwal, P., Sharma, R.K., Bhatia, A., Singh, G., Datta, S.P., Kar, A., Singh, B., Singh, P., Pathak, H., Vyas, A.K. and Jat, M.L.,2014. Conservation agriculture in an irrigated cotton-wheat system of the western Indo-Gangetic Plains: crop and water productivity and economic profitability. Field Crops Res. 158, 24 33.

Derpsch, R., Franzluebbers, A.J., Duiker, S.W., Reicosk, D.C., Koeller, K., Friedrich, T.,

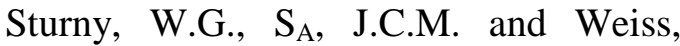
K.2014. Why do we need to standardize no-tillage research? Soil Till.Res. 137:1622.

Dhindwal, As-Hooda, I. S., Malik, R.K. and Kumar, S.2006. Water productivity of furrow-irrigated rain season pulses plorted on raised bed. Indian J. Agron., 51(1): 49-53.

Doorenbos, J and W.O. Pruitt. 1982. Crop water requirements. Irrigation and Drainage Paper No. 24, Rome, Italy.

Ehrler, W. L., Idso, S., B., Jackson, R. D. and Reginato, R. J. 1978b. Diurnal changes in plant water potential and canopy temperature of wheat as affected by drought. Agron. J. 70: 999-1004.

Fahong, W., Xuqing, W. and Sayre, K. 2004. Comparison of conventional flood irrigated, flat planting with furrow irrigated, raised bed planting for winter wheat in China. Field Crops Res. 87, 3542.

Fang, Q., Chen, Y., Li, Q., Yu, S., Luo, Y., Yu, Q. and Ouyang, Z. 2006. Effects of soil moisture on radiation utilization during late growth stages and water use efficiency of winter wheat. Acta Agron. Sin. 32: 861-866

Gao, Y., Duana, A., Qiu, X., Pauline, Li. X., Sun, U. and J. Wang, J. 2013. Modeling evapo-transpiration in maize/soybean strip intercropping system with the evaporation and radiation interception by neighboring species model. Agri Water Manag. 128:110- 119.

Gomez, K. A. and Gomez, A. A. 1984. Statistical Procedures for Agricultural Research 2: 196-211.

Gontia, N.K. and Tiwari, K.N. 2008.Development of crop water stress index of wheat crop for scheduling irrigation using infrared thermometry. Agric Water Manag 95:1144-1152

Govaerts, B., Sayre, K.D., Goudeseune, B., De Corte, P., Lichter, K., Dendooven, L. And Deckers, J. 2009. Conservation agriculture as a sustainable option for the central Mexican highlands. Soil Till Res. 103, 222-230.

Gowda, D.S.S., Singh, G. P. and Singh, A. M. 2011. Relationship between canopy temperature depression, membrane stability, relative water content and grain yield in bread wheat (Triticum aestivum) under heat stress environments. Indian J. Agri. Sci. 81(3): 115-120.

Gupta, R. and Jat, M.L. 2010. Conservation agriculture: addressing emerging challenges of resource degradation and food security in South Asia. In: Behera, U.K., Das, T.K., Sharma, A.R. (Eds.), Conservation Agriculture. Division of Agronomy, Indian Agricultural Research Institute, New Delhi, pp. 1-18 (110012, 216 p.).

Gutierrez, M., Reynolds, M. P., Raun, W. R., Stone, M. L. and Klatt, A. R. 2010. Spectral water indices for assessing yield in elite bread wheat genotypes under well-irrigated, water stressed, and high temperature conditions. Crop Sci. 50: 197-214.

Haddeland, I., Heinkeb, J., Biemansd, H., Eisnere, S., Flörkee, M., Hanasakif, N., Konzmannb, M., Ludwigd, F., Masakif, Y., Scheweb, J., Stackeg, T., Tesslerh, Z.D., Wadai, Y. and Wisseri, D. 2014. Global water resources affected by human interventions and climate change. Proc. Natl Acad. Sci. U. S. A. 111: 3251-3256. 
Humphreys, E., Kukal, S. S., Kaur, A., Thaman, S., Yadav, S., Singh, Y., Singh, B., Timsina, J., Dhillon, S. S., Prashar, A. and Smith, D. J. 2008. Permanent beds for rice-wheat in Punjab, India: Part 2. Water balance and soil water dynamics. In: Humphreys E, Roth $\mathrm{C} \mathrm{H}$. Permanent Beds and Rice-Residue Management for Rice-Wheat Systems in the Indo-Gangetic Plain. Proceedings of a Workshop Held in Ludhiana, India, 7-9 September 2006. ACIAR Proceedings No. 127: 37.

Igbadun, H.E., Mahoo, H.F., Tarimo, A.K.P.R. and Salim, B.A. 2006. Crop water productivity of an irrigated maize crop in Mkoji sub-catchment of the Great Ruaha River Basin, Tanzania. Agri Water Manag. 85, 141-150.

Iqbal, M., Khan, A.G., Hassan, A. and Islam, K.R. 2013. Tillage and nitrogen fertilization impact on irrigated corn yields and soil chemical and physical properties under semi-arid climate. $J$ Sustainable Watershed Sci. Manag. 1: 9098.

Iturbe-Ormaetxe I, Escuredo P.R., Arrese-Igor C. and Becana M. 1998. Oxidative damage in pea plants exposed to waterdeficit or paraquat. Plant Physiol 116: 173- 181.

Jat, M.L., Gathala, M.K., Saharawatd, Y.S., Tetarwale, J.P., Gupta, Raj. And Singh, Yadvinder. 2013. Double no-till and permanent raised beds in maize-wheat rotation of north-western Indo-Gangetic plains of India: Effects on crop yields, water productivity, profitability and soil physical properties. Field Crops Res 149: 291-299

Jat, M.L., Hobbs, P.R. and Singh, Bruno, Gerard, 2014a. Nutrient management and use efficiency in wheat systems of south asia. Adv. Agron. 125: 171-259.

Jat, R.K., Sapkota, T.B., Singh, R.G., Jat, M.L., Kumar, M. And Gupta, R.K. 2014b. Seven years of conservation agriculture in a rice-wheat rotation of eastern Gangetic Plains of South Asia: yield trends and economic profitability. Field Crops Res.164, 199-210.

Jemai, I., Ben Aissa, N., Ben Guirat, S., BenHammouda, M. And Gallali, T., 2013. Impact of three and seven years of notillage on the soil water storage in the plant root zone, under a dry sub humid Tunisian climate. Soil Till Res. 126, 2633.

Kar, G. and Kumar, A. 2009. Evaluation post rainy season's crops with residual soil moisture and different tillage methods in rice fallow of eastern India. Agric Water Manag. 96, 931-938.

Kar, G., Kumar, A., Sahoo, N. and Mohapatra, S. 2013. Radiation utilization efficiency, latent heat flux, and crop growth simulation in irrigated rice during post flood period in east coast of India. Paddy Water Environ. 12, 285-297.

Kaschuk, G., Alberton, O. and Hungria, M. 2010. Three decades of soil microbial biomass studies in Brazilian ecosystems: lessons learned about soil quality and indications for improving sustainability. Soil Biol. Biochem. 42, 1-13.

Kumar, Vineet, Naresh, R. K., Dwivedi, Ashish, Kumar, Ashok; Sahi1, U. P., Singh, S. P., Kumar, Robin and Singh, Vikrant. 2015. Tillage and Mulching Effects on Soil Properties, Yield and Water Productivity of Wheat under various Irrigation Schedules in Subtropical Climatic Conditions. J. Pure Applied Microbi. 9(2): 217-228.

Ladha, J. K., Kumar, V., Alam, M. M., Sharma, S., Gathala, M. K., Chandna, P., Saharawat, Y. S. And Balasubramanian, V. 2009. Integrating crop and resource management technologies for enhanced productivity, profitability and sustainability of the rice-wheat system in South Asia. Integrated Crop and Resource Management in the Rice-Wheat System of South Asia: 69-108.

Li, QuanQi., Chen, Yu Hai., Zhou, Xun BoYu. And Song, Lie. 2009. Effects of irrigation and planting patterns on consumption of soil moisture before sowing and water use 
efficiency in winter wheat. [Chinese] Acta Agronomica Sinica; 35 (1):104-109.

Lopes, M. S. and Reynolds, M. P. 2012. Staygreen in spring wheat can be determined by spectral reflectance measurements (normalized difference vegetation index) independently from phenology. $J$ Exp Bot. pp 1-10 doi:10.1093/jxb/ers071.

Mandhata Singh., Singh, G. R., Singh, V. P. And Singh, D. K. 2012. Effect of moisture regimes and nitrogen levels on production potential water use efficiency and economics of bed planting wheat. New Agriculturist 23 (2):139-143.

Manivannan, P., Jaleel, C.A., Kishorekumar, A., Somasundaram, R., Sridharan, R., Alagu, R., Lakshmanan, G.M. and Panneerselvam, R. 2007. Growth, biochemical modifications and proline metabolism in Helianthusannus $L$. as induced by drought stress. Biointerface 59: 141-149.

Monteith, J. L. 1977. Climate and efficiency of crop production in Britain. Philosophical Transaction of RoyalSociety London 281, 277-294.

Monteith, J.L. 1972. Solar radiation and productivity in tropical ecosystems. $J$. Appl. Eco. 9, 747-766.

Musick, J.T., Jones, O.R., Stewart, B.A. and Dusek, D.A. 1994. Water-Yield relationship for irrigated and dryland wheat in the US southern plains. Agron J, 86, 980-986.

Naresh, R. K., Dhaliwal S. S., Kumar D., Tomar S. S., Misra A. K., Singh S. P., Kumar P., Kumar V. and Gupta R. K. 2014b. Soil physical properties: Water balance and wheat yield under irrigated conditions. African J Agri Res. 9(32): 2463-2474.

Naresh, R. K., Gupta, R. K., Singh, Y. P., Kumar, A., Khilari, K., Singh. P. K., Shahi. U. P., Tomar, S.S. and Yadav, A. K. 2011a. Impact of Resource Conservation Technologies for Sustainability of irrigated agriculture in Uttar Pradesh-India. J Rural Agri Res. 11(1): 13-18.
Naresh, R. K., Gupta, Raj, K., Singh, B., Kumar, Ashok., Shahi, U.P., Pal, Gajendra., Singh, Adesh., Yadav, Ashok Kumar and Tomar, S.S.2010a. Assessment of no-tillage and direct seeding technologies in rice-wheat rotation for saving of water and labour in western IGP. Progressive Agri Int J. 10 (2): 205-218.

Naresh, R.K., Rathore, R.S., Kumar, Parvinder., Singh, S.P., Singh, Adesh and Shahi, U.P. 2014a.Effect of precision land leveling and permanent raised bed planting on soil properties, input use efficiency, productivity and profitability under maize (Zea mays) - wheat (Triticum aestivum L.) cropping system. Indian J Agri Sci; 84 (6): 725-732.

Naresh, R.K., Singh, S.P. and Kumar, Vineet. 2013a. Crop establishment, tillage and water management technologies on crop and water productivity in rice-wheat cropping system of North West India. Int J Sci Life Sci Biotech Pharma Res. 1-12.

Naresh, R.K., Singh, S.P., Singh, A., Kamal, Khilari, Shahi, U.P. and Rathore, R.S. 2012. Evaluation of precision land leveling and permanent raised bed planting in maize-wheat rotation: productivity, profitability, input use efficiency and soil physical properties. Indian J Agri Sci 105 (1): 112-121.

Naroui Rad M.R., Abdul Kadir M. Z.E., Jaafar H. and Gement D.C. 2012. Physiological and biochemical relationship under drought stress in wheat (Triticum aestivum). African J Biot. 11(7): 15471578.

Norman, J.M., Campbell, G.S., 1989. Canopy structure. In: Pearcy, R.W., Ehlereinger,J.R., Mooney, H.A. and Rundel, P.W. (Eds.), Plant Physiological Ecology: Field Methods and Instrumentation. Chapman and Hall, London, pp. 301-325.

Parihar, C.M., Jat, S.L., Singh, A.K., Kumar, B., Yadvinder-Singh Pradhan, S., Pooniya, V., Dhauja, A., Chaudhary, V., Jat, M.L., Jat, R.K. and Yadav, O.P. 
2016a. Conservation agriculture in irrigated intensive maize-based systems of north-western India. Effects on crop yields, water productivity and economic profitability. Field Crops Res. 193, 104116.

Parihar, C.M., Jat, S.L., Singh, A.K., Majumdar, K., Jat, M.L., Saharawat, Y.S., Pradhan, S., and Kuri, B.R., 2017. Bioenergy, biomass water use efficiency and economics of maize-wheat-mungbean system under precision-conservation agriculture in semi-arid agro-ecosystem. Energy 119, 245-256.

Parihar, C.M., Yadav, M.R., Jat, S.L., Singh, A.K., Kumar, B., Pradhan, S., Chakraborty, D., Jat, M.L., Jat, R.K., Saharawat, Y.S. and Yadav, O.P. 2016 b. Long term effect of conservation agriculture in maize rotations on total organic carbon, physical and biological properties of a sandy loam soil in northwestern Indo-Gangetic Plains. Soil Till Res.16: 116-128.

Pathak, H. Saharawat, Y. S. Gathala, M., Mohanty, S. Chandrasekharan and Ladha, J. K. 2011. Simulating the impact of resource conserving technologies in ricewheat system on productivity, income and environment Part I. Greenhouse Gas Sciences Technology 1: 1-17.

Pitman, J.I. 2000. Absorption of photosynthetically active radiation, radiation use efficiency \& spectral reflectance of Bracken [Pteridium aquilinum (L.) Kuhn] canopies. Annals Bot. 85 (Supplement B), 101-111.

Plénet, D., Mollier, A. and Pellerin, S. 2000. Growth analysis of maize field crops under phosphorus deficiency. II. Radiation-use efficiency: biomass accumulation and yield components. Plant Soil 224: 259-272.

Pradhan, S., Sehgal, V.K., Das, D.K., Jain, A.K., Bandyopadhyay, K.K., Singh, R. and Sharma, P.K. 2014. Effect of weather on seed yield and radiation and water use efficiency of mustard cultivars in a semi- arid environment. Agric. Water Manage. $139,43-52$.

Prihar, S. S., Gajri, P. R. and Narang, R. S. 1974. Scheduling irrigation to wheat using open pan evaporation. Indian $J$. Agri. Sci., 44: 567-71.

Quanqi, Li., Zhou, Xunbo, Chen, Yuhai and Yu, Songlie. 2012. Water consumption characteristics of winter wheat grown using different planting patterns and deficit irrigation regime. Agri Water Manag 105: 8-12.

Rahman, M.A., Hossain, S.J., Hossain, M.B., Amin, M.R. and Sarkar, K.K. 2010. Effect of variety and culture method on the yield and yield attributes of wheat. Int J Sus Crop Prod 5 (3): 17-21.

Rajcan, I. and Tollenaar, M. 1999. Source: sink ratio and leaf senescence in maize: I. Dry matter accumulation and partioning during grain filling. Field CropsRes. 60, 245-253.

Ram, Hari, Dadhwal,Vikas., Vashist, Krishan, Kumar. And Kaur, Harinderjit. 2013 Grain yield and water use efficiency of wheat (Triticum aestivum L.) in relation to irrigation levels and rice straw mulching in North West India. Agri Water Manag 128 92-101

Rani, N., Sidhu, B. S. and Beri, V. 2009. Organic rice (Oryza sativa) and wheat (Triticum aestivum) production quality and economics in irrigated agriculture. Indian J. Agric. Sci. 79 (1): 20-24.

Saharawat, Y. S., Singh, Bhagat, Malik, R. K., Ladha, J. K., Gathala, M., Jat, M. L. and Kumar, V.2010. Evaluation of alternative tillage and crop establishment methods in a rice-wheat rotation in north-western IGP. Field Crops Res 11: 260-267.

Schneider, J.R., Caron, B.O., Elli, E.F., Schwerz, F., Rockenbach, A.P. and Engroff, T.D. 2016. Conversion efficiency of photosynthetically active radiationiIn soybean cultivars during planting seasons. Aust. J. Basic Appl. Sci. 10 (15), 209-214.

Sharma, A.K. and Yadav, A. 2010. Enhancing yield and water productivity of wheat 
(Triticum aestivum L.) through furrow irrigated raised bed system in the IndoGangetic Plains of India. Indian J Agri Sci 80 (3): 198-202.

Sharma, A.R., Jat, M.L., Saharawat, Y.S., Singh, V.P. and Singh, R. 2012. Conservation agriculture for improving productivity and resource-use efficiency: prospects and research needs in Indian context. Indian J. Agron. 57, 131-140.

Shefazadeh, M. K., Mohammadi, M. and Karimizadeh, R. 2012. Genotypic difference for heat tolerance traits under real field conditions. J. Food Agric. Environ 10 (1): 484-487.

Singh, Avtar., Kang, J. S., Kaur, Maninder. and Goyal, Ashu. 2010a. Irrigation scheduling in zero-till and bed-planted wheat (Triticum aestivum). Indian J Soil Con; 38(3):194-198.

Singh, Avtar., Kang, J.S., Kaur, Maninder and Goyal, Ashu. 2010b. Irrigation scheduling in zero-till and bed-planted wheat (Triticum aestivum L.). Indian J Soil Con 38(3): 194-198.

Singh, Karmal., Dhindwal, A.S., Dhaka, A.K., Sewhag, Meena and Pannu, R.K. 2015. Water use pattern and productivity in bed planted wheat (Triticum aestivumL.) under varying moisture regimes in shallow water table conditions. Indian $J$ Agri Sci; 85 (8): 1080-1084.

Singh, Y. K. and Katiyar, T. P. S. 2014. Effect of tillage system, irrigation scheduling and depth on growth, yield attribute, yield and water use in wheat (Triticum aestivum). Int J Tropical Agri. 32 (1/2): 512-521

Slatyer, R.1967. Plant-water relationships. New York, NY: Academic Press.

Teixeira, E.I., George, M., Herreman, T., Brown, H., Fletcher, A., Chakwizira, E., DeRuiter, J., Maley, S. And Alasdair, N. 2014. The impact of water and nitrogen limitation on maize biomass and resource-use efficiencies for radiation water and nitrogen. Field Crops Res. 168, 109-118.

Tripathi, S. C. and Singh, R.P. 2007. Effect of Chiseling, green monuring and planting methods on productivity and profitability of rice- wheat cropping system. Indian J.Agron., 52(4): 279-282.

Tuong, T.P., Pablico, P.P., Yamauchi, M., Confesor, R. and Moody, K. 2000. Increasing water productivity and weed suppression of wet seeded rice: effect of water management and rice genotype. Experimental Agric.36, 71-89.

Yoshida.1972. Physiological aspects of grain yield. Ann. Review Plant Physio. 23, 437464.

Zaman, A., Nath, R. and Chaudharu, S. K.2006. Evapotranspiration, water use efficiency, moisture extraction pattern and seed yield of wheat as influenced by irrigation and nitrogen under limited moisture supply condition. Indian Agriculturist 51 (1/2): 19-23.

Zhu H. S. and Huang P. S. 1994. Soil water stress and active oxygen metabolism in rice. J. Nanjing Agric. Univ. 17: 7-11

\section{How to cite this article:}

Vikrant Singh, R. K. Naresh, Vineet Kumar, Mayank Chaudhary, N.C. Mahajan, D.K. Sachan, Akash Pandey, Abhisekh Yadav and Lali Jat. 2018. Effect of Irrigation Schedules and Crop Establishment Methods on Physiological Processes, Light Interception, Water and Crop Productivity of Wheat under a Semiarid Agro-Ecosystem. Int.J.Curr.Microbiol.App.Sci. 7(12): 3427-3451. doi: https://doi.org/10.20546/ijcmas.2018.712.392 